\title{
DRUG THERAPY IN PEPTIC ULCER DISEASE
}

The treatment of peptic ulcer disease has undergone a revolution in the past decade. This revolution, based on advances in cellular biology, pharmacology, and health care delivery, has changed forever the treatment of this major disease. An improved understanding of the regulation and cellular mechanisms of gastric acid secretion has resulted in the development of specific and potent drugs for the treatment of peptic ulcer. These new agents permit clinicians to affect, at specific points, the abnormal secretory and mucosal defense mechanisms associated with peptic ulceration.

Of the new agents, the histamine $\mathrm{H}_{2}$-receptor antagonists are currently the most important. While the incidence of peptic ulcer has been declining in the United States since the mid 1960s, the introduction of effective $\mathrm{H}_{2}$-receptor antagonists led to a further, precipitous fall in patients referred for elective peptic ulcer surgery. Intractability as an indication for operative therapy has become exceedingly rare. Indeed, the circumstances that constitute failure of medical therapy or are indications for surgical therapy in this cimetidine era have yet to be clearly defined.

The contribution of the $\mathrm{H}_{2}$-receptor antagonists and other newer antisecretory drugs to the improved treatment of patients with peptic ulcer disease cannot be overestimated, and yet, future improvements appear likely. An important milestone in the development of potent antisecretory drugs may have been achieved with the synthesis of proton-pump inhibitors. As will be discussed, the evidence is unequivocal that these new agents effectively relieve ulcer pain, promote healing, and reduce short-term ulcer morbidity. It must be pointed out, however, that none of the antisecretory drugs developed to date have been shown to alter the natural history of peptic ulcer disease, i.e., the ulcer diathesis. Currently available agents are essentially palliative; they promote healing of ulcers but do not cure ulcer disease. The next important milestone in the treatment of peptic ulcer disease will be the discovery of drugs which permanently alter the ulcer diathesis.

The purposes of this presentation will be: (1) to discuss the regu- 
lation and cellular mechanisms of acid secretion; (2) to classify drugs used in ulcer therapy according to their sites and mechanisms of action; (3) to discuss the important drugs with respect to their pharmacokinetics, clinical efficacy, and side effects; and (4) to provide a perspective for use of the various agents in peptic ulcer disease and to examine the present and future impact of new drugs on surgery for peptic ulcer disease.

\section{REGULATION OF GASTRIC ACID SECRETION}

Gastric acid secretion is regulated through a complex interaction of nerves, hormones, and local or paracrine agents (Fig 1). Gastric acid is produced by specialized parietal cells contained in the fundic mucosa. Parietal cells secrete hydrochloric acid via the actions of a unique hydrogen-potassium ATPase into the secretory canaliculus, an infolding of the plasma membrane which, in turn,

\section{REGULATION OF ACID}

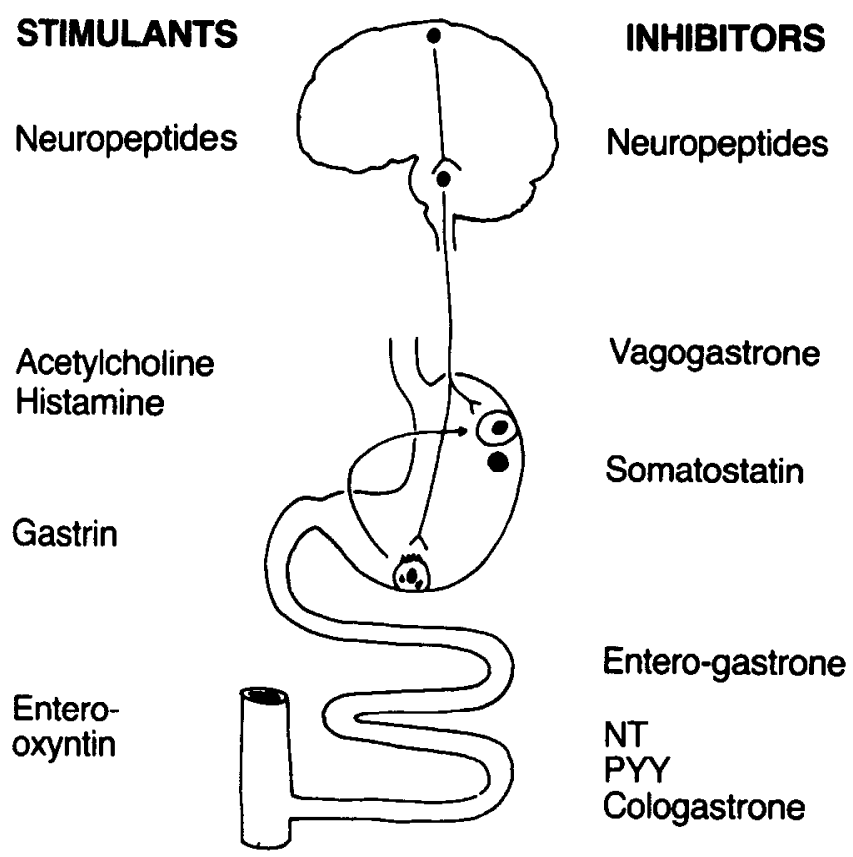

FIG 1.

Regulation of gastric acid secretion. NT-neurotensin; PYY-peptide YY. 
communicates with the gastric lumen. These neurohumoral mechanisms serve to modulate both inhibitory and stimulatory processes. ${ }^{1}$ The human stomach normally contains about 1 billion parietal cells. The parietal cell secretes acid continuously both in the basal and fasting state. The mechanisms underlying this basal acid secretion are poorly understood. In general, we have a better understanding of the processes that stimulate acid secretion than of those that inhibit it.

\section{BASAL ACID SECRETION}

The normal human stomach secretes 2 to $5 \mathrm{mEq}$ of $\mathrm{HCl}$ per hour in the fasting state. Since vagotomy decreases this basal secretion by some $85 \%$, it has been presumed that vagal tone is important in determining the rate of basal acid production. However, $\mathrm{H}_{2}$-receptor blockers have also been demonstrated to inhibit basal acid secretion by about $80 \%$. One might conclude, therefore, that ambient histamine concentration in the interstitial fluid bathing the parietal cell as well as vagal tone are important in sustaining basal acid secretion. Gastrin does not appear to play an important role in basal acid secretion in normal individuals. Patients with the Zollinger-Ellison syndrome, however, may secrete in excess of $10 \mathrm{mEq}$ of acid per hour in the fasting state and, in this pathological condition, basal acid secretion is stimulated by gastrin. Critically ill patients, particularly those who are septic or have increased intracranial pressure, will also have increased "basal" acid secretion.

\section{STIMULATED ACID SECRETION}

Phasic vagal discharge in response to the thought, sight, or smell of food stimulates acid secretion directly by a cholinergic mechanism. Vagal discharge also inhibits gastric somatostatin release. Since somatostatin inhibits parietal cell secretion, inhibition of somatostatin release may be an additional mechanism by which the vagus stimulates acid secretion. The direct cholinergic action of the parietal cell has the more important role, however. The cephalic phase component of acid secretion, as determined by sham-feeding of normal individuals, is about $10 \mathrm{mEq} / \mathrm{hr}$. This vagally controlled component of acid secretion represents approximately $40 \%$ of the maximal acid response to gastrin infusion.

When food enters the stomach, distention triggers neural reflexes and gastrin release is activated. A technique of continuous intragastric titration can be used to estimate the amount of acid the stomach secretes in response to a meal. These estimates range from 15 to 25 $\mathrm{mEq} / \mathrm{hr}$, or approximately $75 \%$ of maximal response to exogenous gastrin or histamine. The reason that the maximal response to a 
meal is somewhat lower than the response to exogenous stimulants may be the concomitant release of somatostatin by food.

Gastrin is the most important mediator of the gastric phase of acid secretion. It is of interest that women secrete twice as much gastrin as men in response to food. Since their meal-stimulated acid response is equal to or less than that of men, the parietal cells in women may be less sensitive to gastrin. The reason for these differences is unknown.

When food enters the small intestine, an additional mechanism for acid secretion is activated. The "intestinal phase hormone" or "enterooxyntin" is released. Purification and chemical characterization of this putative hormone has not been accomplished. Physiological studies suggest that although enterooxyntin is a weak stimulant of acid secretion, it is capable of markedly augmenting the acid response to both submaximal and maximal doses of gastrin and histamine.

\section{INHIBITION OF ACID SECRETION}

Inhibitory regulation of gastric acid secretion is accomplished through central, vagal, gastric, intestinal, and colonic mechanisms. A number of neuropeptides, most importantly bombesin or gastrin-releasing peptide, cause profound inhibition of gastric acid secretion when administered into the lateral cerebral ventricles of rats and dogs. Whether these centrally inhibiting neuropeptides play a physiological role in inhibiting the regulation of acid secretion in humans has not been established. The vagus appears to exert a dual control of acid secretion and gastrin release, modulating both stimulatory and inhibitory actions. After vagotomy, fasting and postprandial plasma gastrin levels increase, indicating that the vagus normally exerts tonic inhibitory regulation on gastrin release. The vagal fibers to the oxyntic mucosa appear to mediate this inhibition. In animals, sham-feeding inhibits pentagastrin-stimulated acid secretion, implying that vagal activation by sham-feeding causes the release of an inhibitory substance. The imputed vagal inhibitor has been referred to as "vagogastrone."

The inhibition of gastric acid secretion relies on negative feedback inhibition of gastrin release by acid and on other neurohumoral mechanisms. When gastric $\mathrm{pH}$ falls to 2.0 , gastrin release ceases. Somatostatin may be an important mediator of this negative feedback loop. In addition, somatostatin is a dominant paracrine agent within the gastric wall to modulate both the release of gastrin from the antrum and the secretion of $\mathrm{H}^{+}$from the oxyntic mucosa. The release of somatostatin is reciprocally linked to that of gastrin; stimulation of somatostatin release is associated with inhibition of gastrin release. Other neuropeptides, contained within vagal fibers in the 
gastric wall, may also play an inhibitory role. Calcitonin-gene-related peptide and substance $P$ are two of many neuropeptides which may be important in modulating acid secretion. Additionally, other neuroendocrine substances, whose release from the oxyntic mucosa are under vagal control, may subserve inhibitory functions. Ulcer recurrence after proximal gastric vagotomy has been postulated to be partly due to interference in the release of these inhibitors of acid secretion.

Intestinal phase inhibition occurs when acid, fat, and hyperosmolar solutions enter the intestine. Acid in the upper intestine releases secretin and another inhibitory agent (bulbogastrone) from the duodenal bulb. High doses of secretin have been demonstrated to inhibit gastric acid secretion, although there is some debate as to whether secretin plays a physiologically-important inhibitory role during normal digestion. Other inhibitory peptides released from the small intestine include gastric inhibitory peptide, somatostatin, neurotensin, and peptide YY (PYY). Each of these agents has been demonstrated to inhibit acid secretion. PYY and another humoral agent yet to be isolated (cologastrone) are also released from the colonic mucosa. It is possible that all of the intestinal and colonic inhibitors act synergistically to turn off acid secretion after a meal.

\section{CELLULAR MECHANISMS OF ACID SECRETION}

Three "on switches" are present in the basolateral membrane of the acid-secreting parietal cell (Fig 2). These are specific receptors for histamine, acetylcholine, and gastrin. ${ }^{2}$ When histamine occupies the $\mathrm{H}_{2}$-receptor, a membrane-bound enzyme, adenylate cyclase, is activated. This activated enzyme converts ATP into cyclic AMP, which then acts as the secondary, intracellular messenger. Increased intracellular cyclic AMP results in a cascade of intracellular events including, sequentially, activation of protein- $\mathrm{C}$ kinase, protein phosphorylation, and stimulation of the $\mathrm{H}^{+}-\mathrm{K}^{+}$-ATPase proton pump, located on the secretory or canalicular membrane of the parietal cell. The proton pump is a unique enzyme system in the plasma membrane of the parietal cell, which causes the secretion of $\mathrm{H}^{+}$into the lumen of the secretory canaliculus in exchange for $\mathrm{K}^{+}$against a steep electrochemical gradient. Within the secretory canaliculus, the $\mathrm{pH}$ approximates 1 . This process represents the final common pathway by which all stimulants affect acid secretion.

When acetylcholine and gastrin occupy their respective receptors, the initial cascade of intracellular events activated is different. In this case, membrane bound phosphoproteins are activated resulting in the conversion of phosphoinositoldiphosphate $\left(\mathrm{PIP}_{2}\right)$ to inositoltriphosphate $\left(\mathrm{IP}_{3}\right)$ and diacylglycerol. The main action of $\mathrm{IP}_{3}$ is to increase intracellular calcium, initially by mobilization of calcium as- 


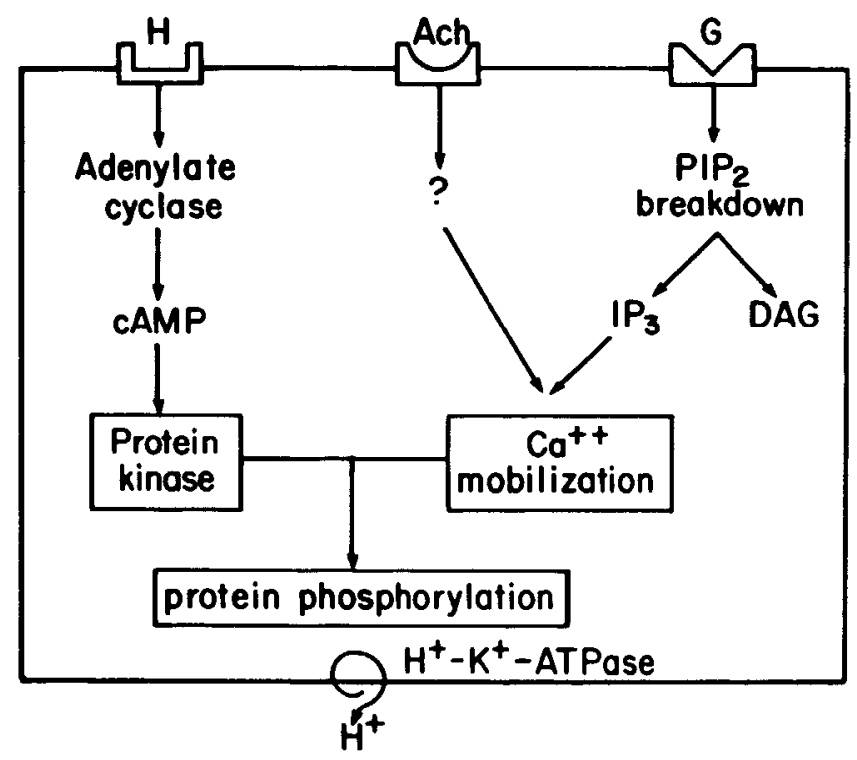

PARIETAL CELL

FIG 2.

Cellular mechanism of acid secretion. H-histamine; G-gastrin; DAG-diacylglycerol.

sociated with the rough endoplasmic reticulum and later by influx of extracellular calcium. Thus, calcium is the secondary intracellular messenger for the actions of gastrin and acetylcholine. Different protein-kinases are subsequently activated for gastrin or acetylcholine, but the final steps of phosphorylation and activation of the $\mathrm{H}^{+}-\mathrm{K}^{+}$ATPase are probably the same for both agents.

It is clear that several classes of drugs that specifically inhibit acid secretion could be developed: those that block the cell-surface receptors for histamine, gastrin, or acetylcholine, those that interfere with intracellular processes, and, finally, those that block the proton pump. Receptor antagonists for histamine, gastrin, or acetylcholine and proton pump inhibitors would be expected to have important advantages in terms of specificity. The revolution in therapy for patients with peptic ulcer has occurred because of the availability of drugs with these characteristics. However, since similar intracellular pathways are utilized by many tissues for generation of second messengers and for intracellular protein phosphorylation, it is unlikely that drugs that selectively inhibit the intracellular processes of the parietal cell will have clinical utility. Figure 3 depicts the drugs used in peptic ulcer therapy according to their site of action. 


\section{SITES OF ACTION OF ANTI-ULCER DRUGS}

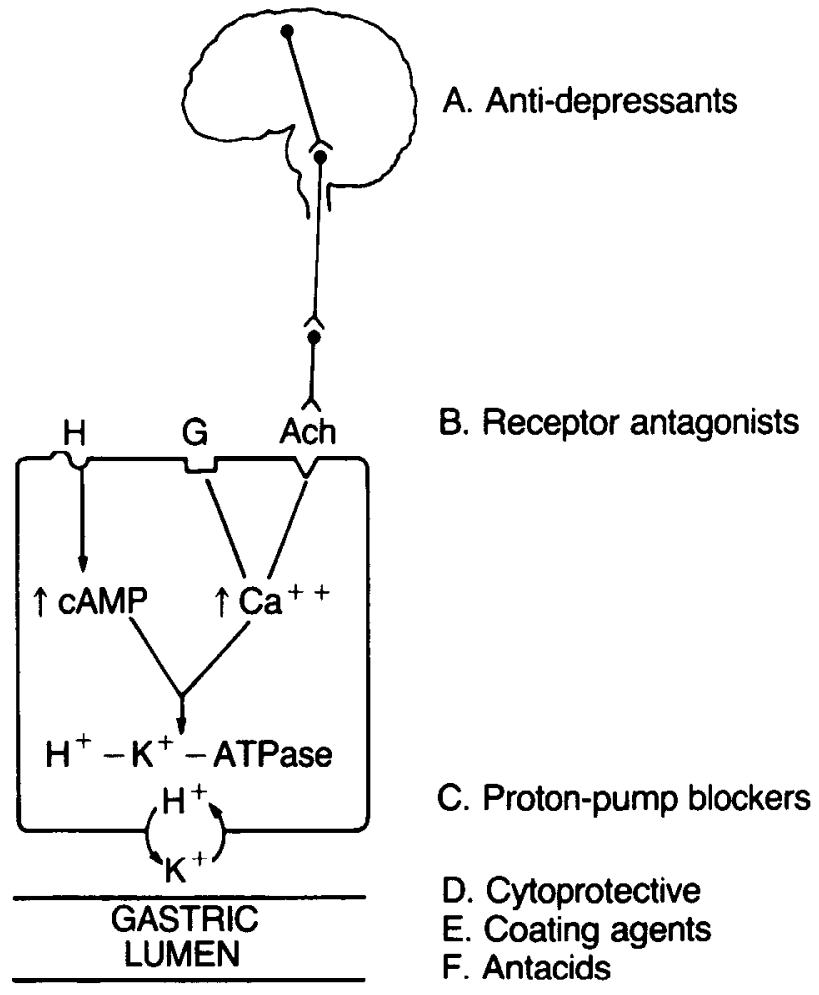

FIG 3.

Drugs used in peptic ulcer therapy classified according to site of action. H-histamine; Ggastrin: Ach-acetylcholine.

\section{PATIIOPIIYSIOLOGY OF PEP'TIC ULCER DISEASE}

\section{EPIDEMIOLOGY}

The incidence of peptic ulcer disease has been declining in the United States for the past 3 decades. The data which support this contention come from studies of military personnel, from the Veterans Administration, and from physician surveys. ${ }^{3-5}$ The reasons for the declining incidence of peptic ulcer disease are unknown. The treatment of peptic ulcer disease has also undergone a radical change, becoming less hospital-oriented. In the decade from 1970 to 1980, hospital admissions for the treatment of duodenal ulcer dropped by $40 \%{ }^{6}$ this drop was broadly paralleled by falling ulcerrelated mortality rates. 
When examined more closely, however, the trends are not uniformly encouraging. While duodenal ulcer admissions have declined sharply for men, they have risen for women. ${ }^{7}$ By 1981 , the prevalence of duodenal ulcer in men and women was equal, erasing a longstanding male predominance. The reasons for these shifting patterns of duodenal ulceration are not known; however, changes in individual exposure to ulcerogenic environmental factors have been suggested. In this regard, cigarette smoking is a major risk factor for duodenal ulcer development and recurrence. Accordingly, hospitalization and mortality rates for patients who smoke have a pattern similar to those for patients with duodenal ulcer. ${ }^{8}$ Cigarette smoking has declined in American men in the past 20 years and only slightly or not at all in women during the same period. ${ }^{9}$ Currently, an equal proportion of middle-aged men and women, the age range most at risk for peptic ulcer disease, smoke cigarettes.

Although the clinical use of $\mathrm{H}_{2}$-receptor antagonists cannot explain changing rates of duodenal ulceration, these drugs have had a major influence on the treatment of patients with established ulcers. Specifically, the use of cimetidine has had an enormous impact on surgical practice. In both the United States and the United Kingdom, the already-declining operative rates for peptic ulcer disease, reflecting generally the declining incidence of the disease, were further decreased by the widespread use of powerful $\mathrm{H}_{2}$-receptor antagonists. ${ }^{10,11}$ There was a virtual elimination of operations performed for intractability. By contrast, operative rates for complicated ulcer disease, e.g., perforation or hemorrhage, have remained largely unchanged to the present.

\section{PHYSIOLOGICAL ABNORMALITIES}

A number of physiological abnormalities have been demonstrated in patients with duodenal ulcer disease; however, a single causative defect has not been elucidated, reflecting the complexity and the probable heterogeneity of the disease process. Investigations of the pathophysiology of duodenal ulcer have focused on three general areas: abnormalities of gastric acid secretion, defects in endocrine control mechanisms, and deficits in mucosal resistance to acid.

Patients with duodenal ulcer have, on average, increased basal secretion of acid. ${ }^{12}$ The mechanism responsible for increased basal secretion is not known, but because basal secretion results from background vagal and histamine stimulation, abnormalities in these two mechanisms have been hypothesized. Duodenal ulcer patients also demonstrate a larger and more prolonged acid secretory response to a meal than normal, ${ }^{13}$ suggesting either an increased sensitivity to acid secretagogues released by meal stimulation or defects in feedback inhibition of acid secretion. As a group, patients with duodenal 
ulcer have an increased secretory capacity for gastric acid. For example, in response to intravenous histamine, the mean peak acid secretion in patients with duodenal ulcer is about $40 \mathrm{mEq}$ of $\mathrm{HCl}$ per hour, while the mean maximal acid output in normal men is approximately $20 \mathrm{mEq} / \mathrm{hr} .{ }^{14}$ However, there is considerable overlap in acid secretion between duodenal ulcer patients and normal subjects, and most patients with duodenal ulcers fall within the range of values for normal. The increased maximal acid output noted in patients with duodenal ulcer may, in part, be due to increased numbers of parietal cells ${ }^{15,16}$ since patients with duodenal ulcer have an average of 1.8 billion cells in their fundic mucosa, about twice the number of normal subjects.

Disturbances in gastric emptying have also been demonstrated. Some patients with duodenal ulcer have accelerated emptying of gastric content, particularly liquids, and duodenal acidification fails to slow emptying appropriately. ${ }^{1 \tau}$ Recently, normal subjects and patients with duodenal ulcer were studied before and after a standard meal. Mean intraduodenal $\mathrm{pH}$ levels were lower and remained below 4.0 for an increased proportion of time in the patients with ulcers. ${ }^{18}$ In patients with ulcer disease, the total acid exposure of the duodenal mucosa after a meal could be several times that of normal subjects. $^{19}$

No striking endocrine abnormalities have been demonstrated in patients with duodenal ulcer. Basal gastrin levels are not elevated and antral gastrin content is normal. Patients with duodenal ulcer tend to release more gastrin after protein meal stimulation, and acidification of the antral lumen is less effective in inhibiting gastrin release. As with acid secretion studies, there is significant overlap with normal subjects. These defects in gastrin release do not seem to be crucial in the development of duodenal ulcers, however.

There is no evidence that altered secretion of inhibitory peptides, including somatostatin, is associated with the development of duodenal ulceration. Intravenous somatostatin inhibits gastrin release and suppresses acid output similarly in ulcer patients and in normal subjects. ${ }^{20}$ Although patients with duodenal ulcers have normal plasma levels of somatostatin, they have reduced tissue levels of somatostatin and decreased numbers of somatostatin-containing cells in antral mucosa. ${ }^{21}$ The significance of these observations remains to be determined.

Increasing attention has focused on mucosal defense mechanisms in the pathogenesis of peptic ulcer. Because many patients with duodenal ulcer secrete acid and pepsin at a rate similar to normal subjects, it is tempting to postulate that they have a defect in mucosal resistance to acid and pepsin. Most studies of human mucosal defenses in peptic ulcer have focused on mucosal prostaglandin or bicarbonate production. Both in animals and in humans, prostaglan- 
dins have been shown to inhibit gastric acid secretion and to accelerate healing of established duodenal ulcers. ${ }^{22}$ Gastric mucosal production of prostaglandin $\mathrm{E}_{2}$ is decreased in patients with active ulcer disease, and prostanoid synthesis is increased in healing ulcers produced by cimetidine. ${ }^{23}$ Whether decreases in mucosal prostanoid content or synthesis cause peptic ulceration or result secondarily from the associated mucosal damage is controversial. Further investigation will be required to define the role of mucosal prostaglandins in the pathogenesis of duodenal ulcer; the subject is an exciting area of research.

Another postulated mucosal protective mechanism is bicarbonate secretion by the gastric and duodenal mucosas. Compared to acid secretion, the amount of bicarbonate secreted by the gastric mucosa is minimal. Because bicarbonate is secreted beneath the mucous gel layer, a small amount is capable of maintaining the $\mathrm{pH}$ of the surface mucous cells near neutrality even in the presence of low luminal $\mathrm{pH}$. Studies by Isenberg and associates have suggested that defective duodenal bicarbonate secretion may exist in patients with duodenal ulcer. ${ }^{24}$ In contrast, Blair and colleagues have concluded that gastric bicarbonate secretion is normal in patients with duodenal ulcer. ${ }^{25}$ Abnormalities in mucosal bicarbonate secretion have no proven pathogenetic significance at the present time.

\section{HISTAMINE BLOCKERS}

\section{CELLULAR MECHANISMS}

Histamine has been recognized for several decades as a potent stimulus of gastric acid secretion. Histamine is secreted directly into the interstitial fluid by cells within the fundic mucosa and reaches neighboring parietal cells by diffusion. Histamine is released in response to a number of physiological stimuli, and blockade of histamine receptors inhibits most forms of stimulated acid secretion. In humans, histamine activation of parietal cells is of central importance in gastric acid production.

There are two classes of histamine receptors. $\mathrm{H}_{1}$ receptors are activated selectively by the histamine agonists such as 2-methylhistamine and are blocked by classic antihistamines such as pyrilamine maleate. $\mathrm{H}_{2}$ receptors, which are distributed widely in the body, are stimulated by selective agents such as 4-methylhistamine, and are blocked selectively by $\mathrm{H}_{2}$-receptor antagonists such as cimetidine. ${ }^{26}$ $\mathrm{H}_{2}$ receptors on gastric parietal cells mediate stimulation of acid secretion, $\mathrm{H}_{2}$ receptors in the uterus mediate relaxation of uterine smooth muscle, and $\mathrm{H}_{2}$ receptors in the heart increase contraction of atrial cardiac muscle. 
Cimetidine, ranitidine, and the newer second generation $\mathrm{H}_{2}$-receptor antagonists bind competitively to parietal cell $\mathrm{H}_{2}$ receptors, producing a potent but reversible inhibition of acid secretion. Because $\mathrm{H}_{2}$ receptors are also found in nongastric tissues, relatively nonselective $\mathrm{H}_{2}$-receptor antagonists such as cimetidine or ranitidine may also exhibit nongastric actions by binding to androgen receptors, to receptors of the hepatic microsomal oxidase system and to receptors on lymphocytes. ${ }^{27-29}$ In addition, both cimetidine and ranitidine cross the blood/brain barrier and bind to receptors in the central nervous system. ${ }^{30,31}$ It is hoped that greater binding specificities of the newer $\mathrm{H}_{2}$-receptor antagonists will be reflected by a smaller number of clinically significant extragastric side effects.

\section{CHEMISTRY}

Histamine $_{2}$-receptor antagonist compounds currently represent the most useful class of drugs for the treatment of duodenal ulcer disease and for clinical conditions characterized by gastric acid hypersecretion. The first $\mathrm{H}_{2}$-receptor antagonists developed closely resembled histamine in chemical structure (Fig 4). The prototype $\mathrm{H}_{2}$ receptor antagonist, burimamide, never achieved clinical usefulness because of a lack of adequate oral bioactivity. The second compound tested, metiamide, demonstrated oral activity but was quickly withdrawn from clinical trials because of associated agranulocytosis. The third compound tested, cimetidine, shares the imidazole ring of histamine. Oxmetidine and etintidine, two drugs currently under development, also contain an imidazole ring with different side chain substitutions. The second clinically important $\mathrm{H}_{2}$-receptor antagonist, ranitidine, was the first effective histamine antagonist with an alkyl furan ring replacing the imidazole ring of native histamine. Subsequent studies have demonstrated that $\mathrm{H}_{2}$-receptor antagonism can also be produced by compounds that do not closely resemble the histamine molecule structurally. Representative members of the ever-expanding list of compounds include famotidine, tiotidine, and the long-acting $\mathrm{H}_{2}$-receptor antagonists, loxtidine and lamtidine.

As a result of these molecular rearrangements, a series of compounds has been produced with increasing potency and efficacy. In addition, the pharmacokinetics have been modified so that $\mathrm{H}_{2}$-receptor antagonism has been prolonged up to and beyond 24 to 48 hours. In addition, some of the newer compounds display very tight binding to receptors with an almost insurmountable antagonism. 


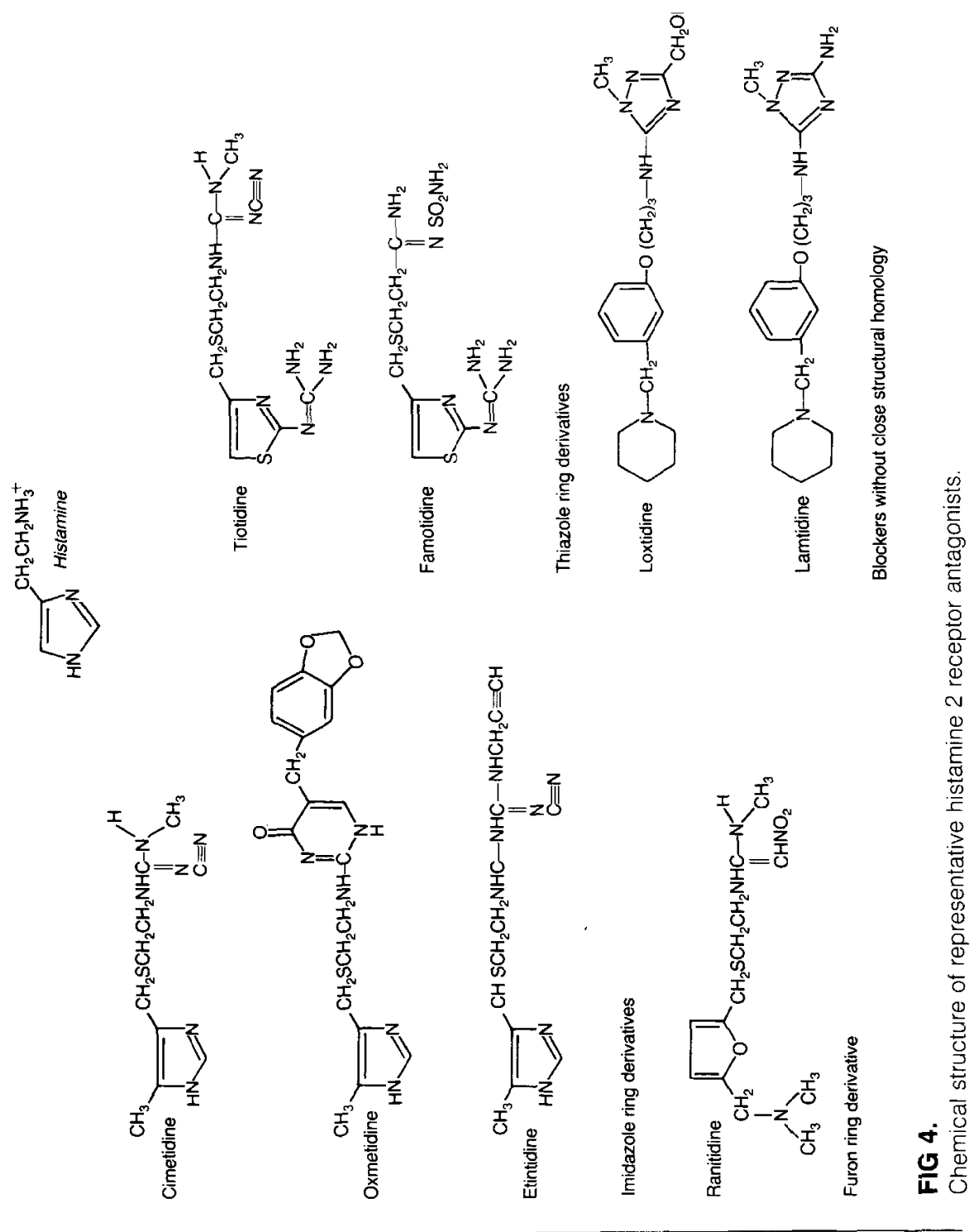




\section{CIMETIDINE AND RANITIDINE}

\section{PHARMACOKINETICS}

The pharmacokinetics of single doses of cimetidine and ranitidine have been studied after intravenous and oral administration in normal subjects and after oral administration in patients with duodenal ulcer. Steady-state pharmacokinetics have also been reported in normal subjects and patients with duodenal ulcers receiving therapeutic doses of the drugs. Except for a modest difference in effects on hepatic microsomal enzymes, the pharmacokinetics of ranitidine are generally quite similar to those of cimetidine. From a pharmacokinetic standpoint, the choice between these two agents is quite arbitrary.

Plasma concentrations of cimetidine and ranitidine peak 1 to 3 hours after oral ingestion. ${ }^{32,33}$ The mean bioavailability of $200 \mathrm{mg}$ of oral cimetidine ranges from $63 \%$ to $78 \%$. A wider range of values are reported for the bioavailability of orally administered ranitidine, varying from $39 \%$ to $87 \%$. The elimination half-life of intravenously administered cimetidine has been reported to be 2.1 to 3.1 hours. Ranitidine has a slightly shorter elimination half-life after intravenous administration of 1.6 to 2.1 hours. Total plasma clearance is similar for both drugs, averaging approximately $600 \mathrm{ml} / \mathrm{min}$. Both cimetidine and ranitidine, along with their products of metabolism, are secreted in the urine. Approximately $50 \%$ of the administered dose is recovered unchanged in the urine within 24 hours, with the major portion of urinary excretion occurring during the first 6 hours after administration. Chronic renal failure significantly prolongs plasma clearance. ${ }^{34}$ A small, but not insignificant, fraction of the drug is eliminated in bile. Modest degrees of hepatic dysfunction have little effect on elimination of cimetidine or ranitidine; however, severe liver dysfunction prolongs the drug half-life. Approximately $3 \%$ of cimetidine is recovered unchanged in the feces.

Many studies have demonstrated a direct correlation between plasma concentration of $\mathrm{H}_{2}$-receptor antagonists and inhibition of intragastric acidity. The $50 \%$ inhibition of pentagastrin-stimulated gastric acid secretion has been commonly used as one bioassay of drug efficacy. The serum concentration of cimetidine that inhibits pentagastrin-stimulated acid secretion by $\mathbf{5 0 \%}\left(\mathrm{IC}_{50}\right)$ has been studied in both healthy subjects and in patients with duodenal ulcers. After intraduodenal administration, the $\mathrm{IC}_{50}$ of ranitidine was 93.6 $\mathrm{ng} / \mathrm{ml}$ in a study reported by Peden et al. ${ }^{35}$ Lebert and co-workers have reported that the mean peak concentration of ranitidine associated with the $50 \%$ suppression of hydrogen ion output was 165 $\mathrm{ng} / \mathrm{ml}^{36}$ The $\mathrm{IC}_{50}$ of cimetidine is higher. Two well-controlled studies on human subjects have reported values of $500 \mathrm{ng} / \mathrm{ml}$ and 780 $\mathrm{ng} / \mathrm{ml}^{37,38}$ The lower $\mathrm{IC}_{50}$ of ranitidine as compared to cimetidine is 
a reflection of its increased potency. Cimetidine and ranitidine have both been shown to suppress basal acid secretion as well as secretion stimulated (by histamine, peptone, or a standard meal) in a dose-dependent manner.

On a molar basis, ranitidine is six to eight times more potent than cimetidine; however, in clinical practice, this difference is not important. Equivalent degrees of acid suppression are easily obtained with equipotent intravenous doses of these agents (cimetidine 300 mg every 6 to 8 hours vs. ranitidine $50 \mathrm{mg}$ every 6 to 8 hours). Single intravenous doses of cimetidine (300 mg) and ranitidine (50 mg) produce equivalent acid suppression in terms of gastric $\mathrm{pH}$, secretory volume, titratable acidity, and total acid ouput. ${ }^{39}$ Both regimens increase intragastric $\mathrm{pH}$ above 3.5 within 30 minutes with maintenance at this level for 3 to 4 hours.

Currently, when oral administration is not possible, most patients receive intravenous $\mathrm{H}_{2}$-receptor antagonists by intermittent bolus administration. However, recent evidence suggests that the continuous infusion of cimetidine is likely to be associated with significant advantages. Ostro and coworkers have reported that the primed, continuous infusion of cimetidine was more effective than bolus delivery in maintaining serum drug concentrations above $0.5 \mu \mathrm{g} / \mathrm{ml}$ and in keeping gastric $\mathrm{pH}$ values above $4.0{ }^{40}$ Twenty-three patients in a medical intensive care unit were examined in this randomized crossover trial. In the bolus regimen, patients received $300 \mathrm{mg}$ intravenous cimetidine every 8,6 , or 4 hours as needed to keep gastric $\mathrm{pH}$ above 4.0. If increasing frequency of dosing was ineffective in maintaining the desired $\mathrm{pH}$, the dose was raised to $400 \mathrm{mg}$ every 4 hours. In the primed infusion regimen, an intravenous bolus of 300 mg was followed by a continuous infusion of $37.5 \mathrm{mg} / \mathrm{hour}$. If gastric $\mathrm{pH}$ was not maintained above 4.0 , the infusion rate was increased to 50,75 , and, finally, $100 \mathrm{mg} /$ hour. Intragastric $\mathrm{pH}$ values were maintained above 4.0 in $87 \%$ of patients receiving primed continuous infusions of up to $50 \mathrm{mg} /$ hour, while $\mathrm{pH}$ values were maintained above 4.0 in only $22 \%$ of patients receiving intermittent boluses of $300 \mathrm{mg}$ every 6 hours. Total drug doses were significantly lower with primed continuous infusions; in addition, therapeutic serum levels of cimetidine were more easily obtained with this regimen. Serum concentrations of cimetidine typically decreased below the therapeutic range of $0.5 \mu \mathrm{g} / \mathrm{ml} 4.3$ hours after a $300 \mathrm{mg}$ bolus. In contrast, serum concentrations of cimetidine were maintained above this level for 12 hours, when a 300-mg bolus was followed by continuous infusion of $37.5 \mathrm{mg} / \mathrm{hour}$.

Pilot studies suggest that administration of cimetidine with total parenteral nutrition formulations provides the same pharmacokinetic advantages as primed continuous intravenous infusions. In addition, admixture of cimetidine with total parenteral nutrition for- 
mulations minimizes fluid volume administration. Delivery of cimetidine in this fashion requires only 4 to $8 \mathrm{ml}$ of extra fluid per day compared to 250 to $500 \mathrm{ml}$ per day when the drug is administered by intermittent boluses 4 times daily. Studies utilizing ranitidine by way of continuous intravenous infusion are currently in progress. There is little experience with ranitidine delivered as a primed continuous infusion.

\section{CLINICAL USE}

More than 100 publications have reported the results of open trials as well as controlled comparisons of cimetidine or ranitidine with placebo or with each other. The evidence is overwhelming that both cimetidine and ranitidine are safe and effective agents for the treatment of patients with duodenal ulcer. The clinical results reported for cimetidine and ranitidine have been roughly equivalent; the efficacy is similar for both compounds when they are administered in doses that produce similar reductions in acid output. For most patients, and in most clinical circumstances, the drugs have similar clinical efficacy (Table 1).

When endoscopic examination is used to evaluate therapeutic results, ulcer healing can be demonstrated in about $70 \%$ of patients receiving either cimetidine or ranitidine by the end of 4 weeks ${ }^{41}$ By 8 weeks, $85 \%$ to $90 \%$ of patients will be ulcer-free and asymptomatic. Acute treatment failures, representing the combination of ulcer nonhealing, patient noncompliance, and drug discontinuance, because of side effects, occur in $10 \%$ to $20 \%$ of patients taking either cimetidine or ranitidine. Acute treatment failures are slightly higher in patients taking cimetidine, representing the slightly higher incidence of drug-related side effects. Most studies of chronic maintenance therapy with $\mathrm{H}_{2}$-receptor antagonists have employed either cimetidine $400 \mathrm{mg}$ or ranitidine $150 \mathrm{mg}$ at night. Ulcer relapse at these doses has been reported in approximately $15 \%$ to $20 \%$ of patients receiving cimetidine or ranitidine. Recurrence of peptic ulceration

\section{TABLE 1.}

Comparison of Cimetidine and Ranitidine in Treatment of Peptic Ulceration (\% of Patients)

\begin{tabular}{lcc}
\hline Results & Cimetidine & Ranitidine \\
\hline Relief of acute pain & 75 & 75 \\
Ulcer healing at 4 weeks & $60-80$ & $60-75$ \\
Ulcer healing at 8 weeks & $85-95$ & $80-90$ \\
Acute treatment failures & $20-30$ & $10-15$ \\
Maintenance treatment failures & $15-25$ & $10-25$ \\
Posttreatment relapse at 1 year & 50 & 50 \\
\hline
\end{tabular}


after cessation of $\mathrm{H}_{2}$-receptor blockade has been reported in greater than half of patients within 1 year, indicating that truly effective maintenance therapy means a commitment to continuous life-long medication in most patients.

\section{SIDE EFFECTS}

A variety of side effects have been noted for the currently available $\mathrm{H}_{2}$-receptor antagonists. The overall incidence of adverse effects is approximately $4 \%-5 \%$. Most of the clinically significant adverse effects result from nonspecific blockade of extragastric $\mathrm{H}_{2}$ receptors. In addition to the effects of nonspecific blockade, the chronic suppression of gastric acid secretion may, at least theoretically, disrupt normal gastric physiologic functions and predispose to longterm complications due to bacterial colonization of the stomach or to disturbances of gastric endocrine regulation. In general, both cimetidine and ranitidine cause similar side effects, and, in most instances, the frequency of complications is similar for the two agents. The higher rate of complications reported in the past for cimetidine relative to ranitidine probably reflected greater experience with the former drug.

A number of dose-dependent neuropsychiatric effects have been reported with the use of cimetidine..$^{42-45}$ Agitation, confusion, lethargy, and mental depression have been most frequently noted in elderly patients and in those with hepatic or renal dysfunction in whom drug metabolism is altered. Significantly increased penetration of cimetidine into the cerebrospinal fluid has been reported for patients with hepatic disease relative to normal patients. Symptoms may reflect interaction of cimetidine with central nervous system receptors. When cimetidine administration has been reduced or eliminated, symptoms have rapidly disappeared. Significant neuropsychiatric effects reported for ranitidine also rapidly reverse with appropriate dose reduction.

Histamine receptors have been reported on the surface of subpopulations of suppressor T-lymphocytes and histamine may suppress immunologic function. Theoretically, $\mathrm{H}_{2}$-receptor antagonists could augment cell-mediated immunity by blocking these receptors. $\mathrm{Ci}$ metidine, but not ranitidine, has been demonstrated in vitro to bind to lymphocyte receptors, with subsequent stimulation of cell-mediated immunity. ${ }^{46}$ To date, clinically important expression of such lymphocyte interactions has not been reported. ${ }^{47}$ Agranulocytosis and thrombocytopenia, which occur rarely with cimetidine, has also been reported with ranitidine. ${ }^{48}$

Cimetidine also binds avidly to receptors of the hepatic microsomal oxidase system. As a result of this interaction, cimetidine increases the blood levels and pharmacologic effects of drugs that de- 
pend on hepatic metabolism. Such medications include warfarin, phenytoin, diazepam, propranolol, theophylline, and shlormethiazole. ${ }^{4-54}$ Dosage adjustments must be made for these and other similarly metabolized drugs when cimetidine therapy is employed. Interactions with warfarin, theophylline, and phenytoin have been shown to be clinically significant. Ranitidine has less effect on hepatic transformation of therapeutic agents, although it does interact with the oxidase system. In addition to inhibiting the hepatic microsomal enzyme system, cimetidine and ranitidine also decrease hepatic blood flow. ${ }^{55,56}$ The decrease in hepatic blood flow caused by these $\mathrm{H}_{2}$ receptor antagonists has been shown to interfere with metabolism of drugs such as propranolol and lidocaine, which are cleared by the liver. Transient increases in serum transaminase levels have been reported in patients receiving both cimetidine and ranitidine. Infrequent reports of possible drug-associated hepatitis have appeared for both agents. Animal studies of cimetidine and ranitidine, however, have failed to show significant dose-related hepatic toxicity.

A number of endocrine abnormalities have been reported in the patients receiving cimetidine. Cimetidine binds to androgen receptors, and the intravenous administration of cimetidine consistently produces increases in serum prolactin levels. ${ }^{57}$ Galactorrhea is occasionally noted with prolonged use of this medication. Gynecomastia has been reported in approximately $4 \%$ of patients treated with long-term high doses of cimetidine ${ }^{58}$ Ranitidine is also believed to interact with testosterone receptors and seems to possess modest antiandrogenic activity. The prolonged use of ranitidine has been associated with gynecomastia and impotence.

\section{SECOND-GENERATION HISTAMINE BLOCKERS}

Currently, a large number of $\mathrm{H}_{2}$-receptor antagonists are in various stages of pharmacological development and clinical testing. These compounds represent further refinements in potency, selectivity, and duration of action relative to currently available drugs. Famotidine, the first of the agents, has rapidly achieved clinical acceptance. Several more of these agents appear destined for clinical introduction in the next several years.

The first new $\mathrm{H}_{2}$-receptor blocker is famotidine. Famotidine is based on a thiazole ring structure in contrast to the imidazole ring of cimetidine or the furan ring of ranitidine. Famotidine has the advantages of a greater potency and longer duration of action than either cimetidine or ranitidine. In normal human subjects, a 20-mg dose of famotidine resulted in $90 \%$ suppression of pentagastrinstimulated gastric acid output, compared with a $55 \%$ suppression of acid output by $300 \mathrm{mg}$ of cimetidine. ${ }^{59}$ In addition, the duration of acid suppression was prolonged relative to the actions of cimetidine. 
Pentagastrin-stimulated acid secretion was less than 50\% of control values 12 hours after an oral dose of $20 \mathrm{mg}$ of famotidine. The volume of gastric secretion was also significantly decreased. McCallum and co-workers have reported that $5 \mathrm{mg}$ famotidine is equipotent with $300 \mathrm{mg}$ of cimetidine but with a longer duration of action. ${ }^{60}$ Famotidine has also been demonstrated to inhibit acid secretion stimulated by histamine, gastrin, or 2-deoxyglucose. Famotidine does not appear to bind to hepatic microsomal enzyme systems as avidly as cimetidine and, in contrast to cimetidine, does not affect the pharmacokinetics of diazepam (which is eliminated by hepatic metabolism) or procainamide (eliminated by tubular secretion). ${ }^{61}$

Three large, prospective, controlled studies have compared famotidine to ranitidine in the short-term treatment of acute ulceration (Table 2 ). The results were remarkably similar for all three studies. ${ }^{62-6+}$ Endoscopically documented healing rates of greater than $90 \%$ were observed at 8 weeks when famotidine was administered at $40 \mathrm{mg}$ once per day. Healing rates were not significantly different between patients who received famotidine and patients who received ranitidine $150 \mathrm{mg}$ twice per day. When famotidine was administered at a dose of $20 \mathrm{mg}$ at bedtime as maintenance therapy, the cumulative 12-month relapse rate was $23.3 \% .{ }^{65}$ Administration of famotidine at a dose of 40 mg resulted in a similar 12 -month relapse rate of $24.8 \%$, while patients treated with placebo had significantly greater ulcer recurrence rates $(56.8 \%)$. On the basis of these data, a dose of $20 \mathrm{mg}$ at bedtime has been proposed as a maintenance dose for famotidine. The postmarketing safety record of famotidine is not as extensive as that of cimetidine or ranitidine.$^{65}$ Case reports suggest, however, that the nature and frequency of adverse effects associated with famotidine will be similar to those observed with cimetidine and ranitidine.

Etintidine, a new $\mathrm{H}_{2}$-receptor antagonist recently entered into clinical trials, may circumvent some of the problems associated with cimetidine use. Etintidine is structurally similar to cimetidine, differing only by the addition of an ethynyl group to the side chain of the parent compound. Animal studies have indicated that, on a molar basis, etintidine is approximately twice as potent as cimetidine ${ }^{66}$ In patients with duodenal ulcer disease, a $300-\mathrm{mg}$ dose of etintidine was significantly more effective than the same dose of cimetidine in suppressing meal-stimulated acid secretion. ${ }^{67}$ The mean acid reduction at 4 hours after administration of the drug was $94 \%$ for etintidine in comparison to $80 \%$ for cimetidine. At these doses, other pharmacokinetic parameters were not significantly different.

The greatest difference between etintidine and cimetidine is illustrated by the dose response curves, which differ in both position and slope (Fig 5). The etintidine curve lies to the left of the cimetidine curve, indicating generally greater potency ${ }^{67}$ While greater potency alone is not therapeutically significant, this difference is ac- 


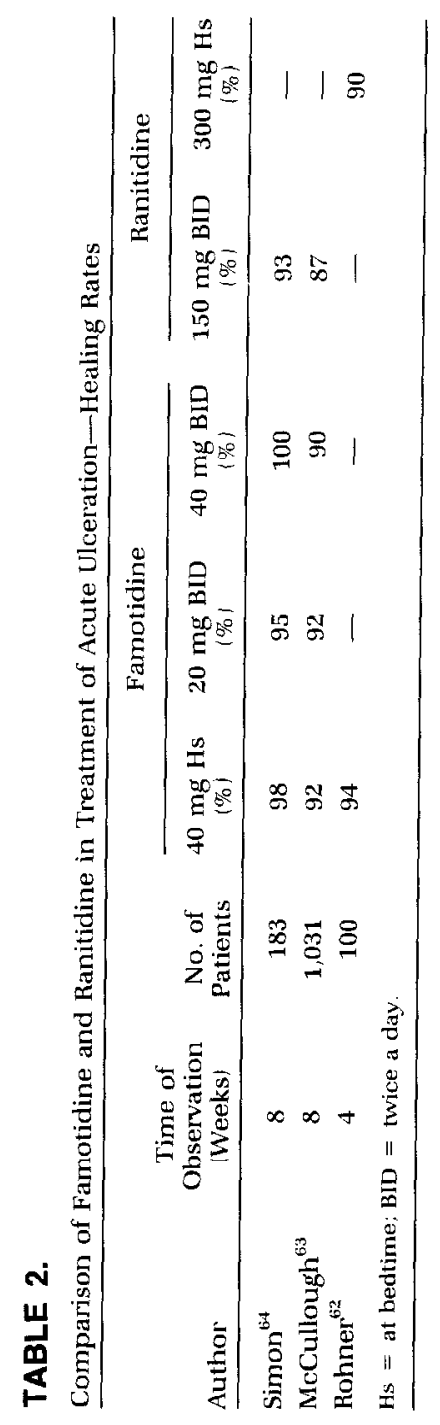

Curr Probl Surg, January 1989 


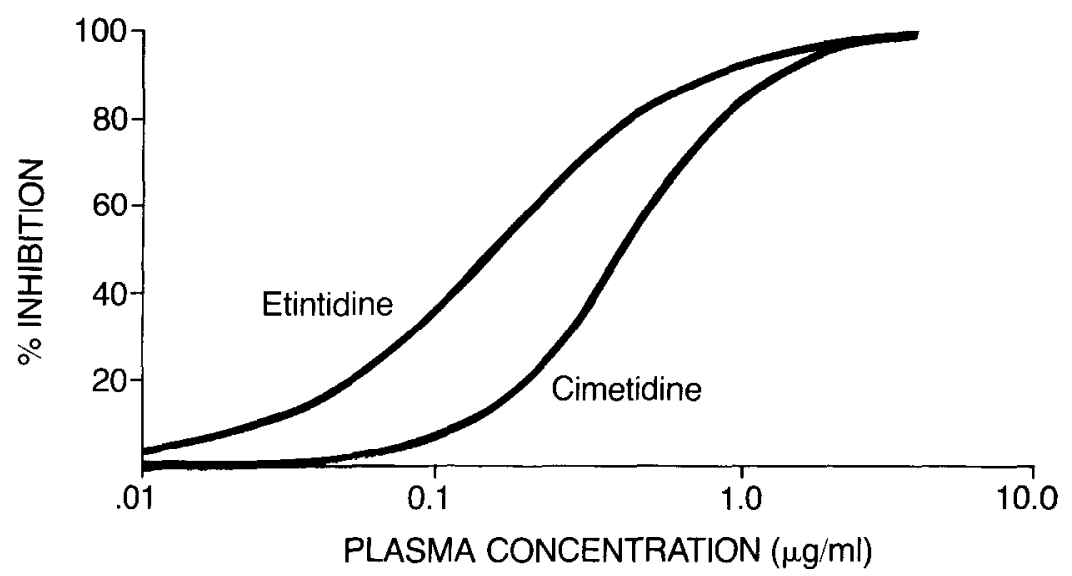

FIG 5.

Clinical pharmacology of etintidine in patients with duodenal ulcer. (Adapted from Brater DC, Meyers WM Jr, Dandekar KA, et al: Eur J Clin Pharmacol 1982; 23:495-500.)

centuated at low plasma concentrations. At low levels, etintidine is significantly more effective in suppressing acid secretion than cimetidine. These differences may have practical importance in certain clinical circumstances. For example, if the clinical goal is $50 \%$ inhibition of meal-stimulated acid secretion, etintidine is three times more potent than cimetidine. This difference might be therapeutically beneficial. Alternatively, if the goal is an $\mathbf{8 0 \%}$ suppression of acid, etintidine is less than twice as potent as cimetidine; the clinical value of such a difference is probably minimal. Controlled clinical trials will be needed to determine if this drug is superior to cimetidine or ranitidine in the treatment of patients with active peptic ulcer disease.

The very extensive clinical experience with cimetidine and ranitidine has demonstrated that these drugs produce similar clinical results when administered at doses that produce equivalent acid suppression. Neither drug demonstrates total efficacy for the healing of acute ulceration or for maintenance of healing. Drug failures probably reflect the incomplete suppression of stimulated acid secretion by cimetidine or ranitidine. Clinical failures may also be due to a lack of effect of $\mathrm{H}_{2}$-receptor antagonists on gastric mucosal defense mechanisms. This lack of complete efficacy has been shared by all the $\mathrm{H}_{2}$-receptor antagonists studied to date. The mechanisms of action of etintidine and famotidine are not different from those of the currently employed $\mathrm{H}_{2}$-receptor blockers and, therefore, these newer agents may also share these shortcomings. 


\section{PROTON PUMP BLOCKERS}

\section{CELLULAR MECHANISMS}

Acid secretion by the parietal cell is due to an enzymatic pump which transports hydrogen ions from the parietal cell cytoplasm into the lumen of the secretory canaliculus in exchange for potassium. This hydrogen-potassium ATPase utilizes energy derived from the hydrolysis of ATP to transport the hydrogen ions against a steep electrochemical gradient. The proton pump is tissue-specific, demonstrated only in gastric parietal cells. Omeprazole is the first of a new class of compounds which selectively blocks this proton pump. Because the proton pump represents the terminal stage of the acid secretory process, omeprazole effectively blocks all forms of stimulated acid secretion-histaminergic, gastrinergic, and cholinergic. ${ }^{68-70}$

Omeprazole is a weak base with a $\mathrm{pK}_{\mathrm{a}}$ of 4 . The agent is nonreactive at a neutral $\mathrm{pH}$ but becomes activated within the secretory canaliculus at a $\mathrm{pH}$ less than 3 . In its activated state, omeprazole interacts with the membrane-bound pump. In addition, because omeprazole is a weak base, the drug accumulates in the acidic environment of the parietal cell. ${ }^{71}$ Omeprazole has not been demonstrated to accumulate in any other organ, nor does it affect any other known enzyme systems. When all parietal cell binding sites are occupied, acid secretion is completely inhibited; omeprazole is the first compound capable of producing true anacidity.

Omeprazole has not been shown to affect pepsin secretion to the same extent to which it inhibits acid secretion. ${ }^{72}$ This observation is consistent with the proposed selective site of action. Small decreases in pepsin secretion may be observed during omeprazole therapy; however, they are probably secondary to decreased mucosal acid secretion or to decreased mucosal metabolic activity. Omeprazole does not affect basal or pentagastrin-stimulated intrinsic factor secretion. $^{73}$

Short-term treatment with omeprazole results in increased levels of circulating gastrin. ${ }^{74}$ Increases in serum gastrin concentrations are probably secondary to the pronounced reduction in intragastric acidity with concomitant loss of inhibitory feedback by luminal acid on the gastrin cell. Serum gastrin concentrations return to normal within 1 to 2 weeks after stopping omeprazole therapy. No significant differences have been observed in plasma concentrations of any other peptides involved in gastrointestinal function during omeprazole administration. Single oral doses of omeprazole up to $90 \mathrm{mg}$ have been demonstrated to have no significant effect on solid or liquid gastric emptying rates in patients with duodenal ulcer disease. ${ }^{75}$ 


\section{CHEMISTRY}

Omeprazole is a substituted benzimidazole (Fig 6).

\section{PHARMACOKINETICS}

Short-term studies in normal subjects have demonstrated that oral doses of omeprazole from 20 to $30 \mathrm{mg}$ result in almost complete inhibition of maximally stimulated gastric secretion within 6 hours. ${ }^{72}$ At 24 hours after administration of this dose, $60 \%$ to $70 \%$ reduction in stimulated acid secretion persists. ${ }^{76}$ Omeprazole administration at $30 \mathrm{mg}$ once per day reduces nocturnal acidity by approximately $75 \%$ while $\mathbf{4 0} \mathrm{mg}$ once daily has been reported to reduce 24-hour median acid secretion by almost $100 \%{ }^{77,78}$ Repeated daily doses of omeprazole result in increasing inhibitory action on gastric secretion which stabilizes after about 3 days. ${ }^{7}$

Because of its $\mathrm{pK}_{\mathrm{a}}$, omeprazole is slightly soluble in water of neutral $\mathrm{pH}$, but very soluble in alkaline solutions. Omeprazole is degraded very rapidly in aqueous solutions of low $\mathrm{pH}$ and, as a result, various oral formulations have been developed to limit intragastric degradation. These formulations also serve to improve systemic bioavailability. The mean time to attain maximum plasma concentrations is highly dependent on the formulation of the drug. In general, maximal concentrations are achieved between 2 and 5 hours when enteric-coated granules of the drug are employed ${ }^{56}$ When buffered solutions of the drug are employed, bioavailability averages about $50 \%$; with the enteric-coated formulations, approximately $65 \%$ systemic availability is achieved ${ }^{81}$ The drug is absorbed best when administered on an empty stomach and most studies have employed administration before the morning meal. ${ }^{82}$

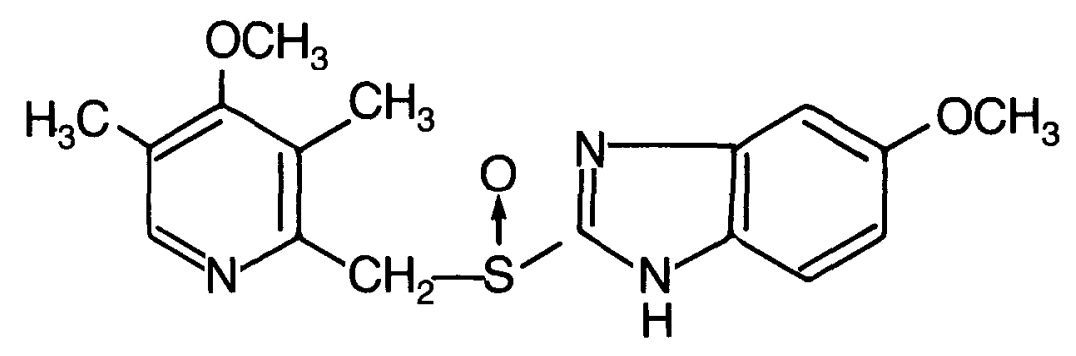

\section{Omeprazole}

\section{FIG 6.}

Chemical structure of omeprazole. 
Autoradiographic studies in animals have demonstrated a rapid distribution of intravenously administered omeprazole. In rats, after 4 hours, the drug is detected in appreciable quantities only in the gastric mucosa, with trace amounts present in the liver, gallbladder, and central nervous system. ${ }^{83}$ Omeprazole seems to be transported in plasma bound to protein. Approximately $95 \%$ of the drug is transported in association with serum albumin and $\alpha-1$ acid glycoprotein.

Omeprazole is eliminated rapidly and almost completely by metabolism. Three metabolites have been identified in human plasma-omeprazolesulphone, omeprazolesulfide, and hydroxyomeprazole. ${ }^{78}$ Urinary excretion accounts for $75 \%$ to $80 \%$ of metabolic clearance, while approximately $20 \%$ is detected in the feces. ${ }^{83}$ Studies in normal human volunteers have demonstrated that omeprazole is eliminated from the plasma with a half-life of between $1 / 2$ and $1 \frac{1 / 2}{2}$ hours. However, while omeprazole dose-dependently inhibits gastric secretion, its antisecretory activity does not correlate with peak plasma concentrations. Indeed, in animal studies, omeprazole markedly inhibits acid secretion long after plasma levels have decreased below detection limits. ${ }^{84}$ This seeming paradox is explained by the accumulation and prolonged action of omeprazole at its site of action within the parietal cell.

\section{CLINICAL USES}

Compared with $\mathrm{H}_{2}$-receptor antagonists, omeprazole accelerates ulcer healing and provides superior symptomatic relief in patients with acute peptic ulceration. Open studies in patients with endoscopically proven duodenal ulcers have demonstrated complete healing in $80 \%$ of patients after 2 weeks and in $95 \%$ of patients after 4 weeks of treatment with omeprazole at 30 to $40 \mathrm{mg}$ once daily. ${ }^{85}$ At doses above $20 \mathrm{mg} /$ day, a significant inhibition of peak acid output, marked relief of epigastric pain, and decreased need for supplemental antacid therapy have been demonstrated in several studies of patients with acute duodenal ulceration. There does not appear to be any clinically significant advantage in increasing the omeprazole dose to greater than $20 \mathrm{mg}$ daily. In addition, the inclusion of an initial loading dose does not influence the rate of ulcer healing or the rapidity of symptomatic relief compared with the same treatment not preceded by loading dose ${ }^{86,87}$ As with most other forms of therapy, duodenal ulcers are more difficult to heal in patients who smoke compared to nonsmokers.

Omeprazole 20 to $40 \mathrm{mg}$ daily has been compared with ranitidine $150 \mathrm{mg}$ twice daily, and cimetidine $1,000 \mathrm{mg} /$ day in patients with acute duodenal ulceration. At 4 weeks after initiation of therapy, $92 \%$ to $100 \%$ of ulcers treated with omeprazole were healed by endo- 
scopic examination. ${ }^{81}$ These results are superior to those obtained with ranitidine $(63 \%$ to $78 \%$ healing rate) and with cimetidine $145 \%$ to $84 \%$ healing ratel. Recently, Tytgat and coinvestigators have reported that $40 \mathrm{mg}$ daily of omeprazole is highly effective therapy in patients with peptic ulcers resistant to cimetidine therapy. ${ }^{87}$ At this high dose, omeprazole nearly completely abolished acid secretion. At 4 to 6 weeks, $100 \%$ of the ulcers in the 10 treated patients were healed.

As is the case for cimetidine or ranitidine therapy, peptic ulceration recurs in a high percentage of treated patients after cessation of omeprazole therapy. Omeprazole does not affect the underlying ulcer diathesis. Lauritsen and coworkers reported, in patients treated with omeprazole, that peptic ulcers recurred in $45 \%$ when the drug was stopped ${ }^{88}$ Walan and associates have reported no significant difference in recurrence rates or time of recurrence in patients treated initially with either omeprazole or ranitidine. ${ }^{89}$ To date, no studies employing omeprazole for chronic maintenance therapy for duodenal ulceration have been reported. Concerns about the safety of chronic omeprazole administration account for this lack of longterm therapeutic trials.

\section{SIDE EFFECTS}

Omeprazole inhibits the oxidative metabolism of some drugs by the hepatic microsomal enzyme system. ${ }^{90}$ Studies in normal human subjects have demonstrated that omeprazole significantly increases plasma diazepam concentration and significantly decreases total body clearance. ${ }^{91}$ Hepatic clearance of antipyrine is reduced by approximately $15 \% .{ }^{92}$ However, animal studies have suggested that omeprazole interference with the hepatic metabolism of drugs is significantly less than that produced by cimetidine.

Prolonged toxicological studies in various animal species have shown that high doses of omeprazole can produce histologic abnormalities in the gastric mucosa. During long-term treatment with omeprazole, 40 to $400 \mathrm{mmol} / \mathrm{kg}$ per day, mucosal endocrine cell hyperplasia was observed. ${ }^{93}$ In some of the treated rats, enterochromaffin-like cells had formed carcinoid tumors. Within some of the carcinoid tumors, growth of abnormal endocrine cells was noted into the submucosa. Hyperplasia of oxyntic mucosal cells has also been observed in dogs and in mice, although in these species the differences are much less notable than in rats, and tumor production has not been observed.

Larsson and coworkers have noted that enterochromaffin-like cell hyperplasia in the rat is directly correlated with elevated circulating gastrin levels. ${ }^{94}$ The degree of hypergastrinemia is, in turn, dependent on the degree of gastric acid inhibition produced by omepra- 
zole. The currently available data suggest that the hyperplasia of enterochromaffin-like cells is not induced directly by omeprazole, but is a physiological response to prolonged hypergastrinemia. Shortterm treatment with omeprazole does cause elevations in the serum gastrin concentrations in patients with duodenal ulcer disease and in normal human volunteers, but these increases are not of the magnitude of those reported in animal toxicology studies. Currently available data do not support a carcinogenic risk during short periods of treatment for duodenal ulcer patients. In humans, only patients with Zollinger-Ellison syndrome have received long-term, continuous omeprazole administration. Hyperplasia of gastric endocrine cells during long-term therapy for the Zollinger-Ellison syndrome has not been observed. However, because of the theoretical disadvantages of long-term chronic anacidity, omeprazole dosages in human patients should be titrated to achieve an acid production of approximately $10 \mathrm{mEq} / \mathrm{hr}$ in the hour preceding the next dose. Total anacidity is not necessary for ulcer healing and is probably undesirable.

Another concern regarding the long-term use of omeprazole has been bacterial overgrowth in the achlorhydric stomach. In 10 healthy volunteers given $30 \mathrm{mg}$ of omeprazole for 14 days, mean nocturnal intragastric acidity was decreased by $75 \% .^{95}$ Significant increases in bacterial counts and in concentrations of nitrites and nitrosamines were noted. Three days after cessation of the drug, these alterations had completely reversed. To date, there have been no reports of illness caused by bacterial overgrowth in patients treated with omeprazole.

Because of these findings and other theoretic concerns about the potential disruption of gastric physiologic mechanisms by chronic anacidity, some workers have expressed reluctance to employ longterm maintenance with omeprazole. An attractive alternative might be to use omeprazole for short-term (4 to 8 weeks) treatment of acute duodenal ulceration. Because no data are presently available to support the use of omeprazole maintenance therapy once ulcers have healed, maintenance therapy with a long-acting $\mathrm{H}_{2}$-receptor antagonist could then be employed chronically. Famotidine, with its long duration of action and potential for once-daily administration, would be an exciting new agent in such a therapeutic scheme.

\section{SELECTIVE ANTICHOLINERGIC DRUGS}

\section{CELLULAR MECHANISMS}

Anticholinergic agents decrease acid secretion by blocking muscarinic receptors for acetylcholine. In both experimental animals and humans, antimuscarinic agents are equipotent with histamine 
receptor antagonists in inhibiting stimulated acid secretion. However, for nonselective anticholinergic drugs such as atropine and propantheline bromide, unpleasant side effects such as dry mouth, blurred vision, urinary retention, tachycardia, and drying of bronchial secretions are frequent. These side effects limit the amount of drug that can be administered to humans. For atropine, limiting effects usually occur at doses lower than those required to significantly inhibit acid secretion. Currently available anticholinergic drugs, in doses tolerable to human subjects, decrease food-stimulated acid secretion by only $30 \%$, approximately half the decrease obtained with $\mathrm{H}_{2}$-receptor antagonists. Consequent to the introduction of cimetidine and ranitidine, anticholinergic agents were virtually abandoned in the treatment of patients with peptic ulceration.

Pirenzepine is a selective anticholinergic agent, a member of a new class of antimuscarinic drugs that may again permit the use of antimuscarinic agents in the treatment of peptic ulceration. Pirenzepine is considered "selective" because it specifically interacts with muscarinic receptors located on postganglionic cholinergic nerves of the stomach $\left(\mathrm{M}_{1}\right.$ receptors) and not with the classic $\mathrm{M}_{2}$ cholinergic receptors of parietal cells, pupil, bladder, or cardiac muscle ${ }^{96,97}$ Recent investigations have suggested that $M_{1}$ receptors are located within the intramural myenteric plexus of the gastrointestinal tract. As a result of this receptor selectivity, pirenzepine effectively inhibits vagally stimulated acid secretion while causing almost no undesirable cardiac, visual, or urinary side effects. ${ }^{98,99}$ Pirenzepine does not exhibit muscarinic agonist activity nor $\mathrm{H}_{2}$-receptor blocking activity.

\section{CHEMISTRY}

Pirenzepine is a pyrido-benzodiazepine compound (Fig 7). The drug is structurally similar to imipramine. However, unlike imipramine, it is without central nervous system activity because of poor penetration of the blood/brain barrier.

\section{PHARMACOKINETICS}

Like the classic antimuscarinic drugs, pirenzepine demonstrates dose-related anticholinergic activity in both animals and in man. However, unlike the classical drugs, pirenzepine inhibits gastric acid secretion at doses which do not significantly affect salivation, heart rate, ocular function, urinary bladder function, or gastrointestinal motility. The relatively low nongastric anticholinergic activity of pirenzepine is reflected by the lower incidence of undesirable anticholinergic side effects in therapeutic trials of the drug.

In studies involving both animals and man, pirenzepine administered orally, subcutaneously, or intravenously, produced dose-de- 
<smiles>CN1CCN(CC(=O)O)CC1C=O</smiles>

Pirenzepine

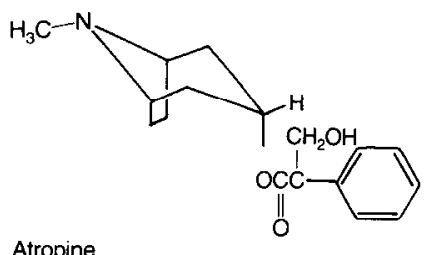

Atropine<smiles>CC(C)N(C)CCOC(=O)C1c2ccccc2Oc2ccccc21</smiles>

Propantheline bromide

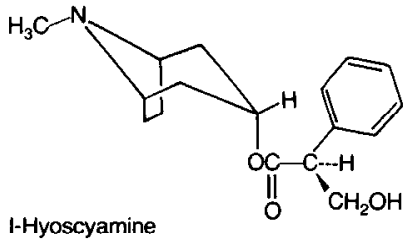

\section{FIG 7.}

Chemical structure of pirenzepine and nonselective anticholinergic drugs.

pendent inhibition of gastric acid secretion stimulated by pentagastrin, histamine, bethanechol, or a test meal. ${ }^{100}$ Pirenzepine markedly inhibits gastric acid secretion due to vagal stimuli such as sham feeding, insulin-induced hypoglycemia, or fundic distention ${ }^{101}$ It is somewhat less effective in inhibiting the effects of direct stimuli such as histamine and pentagastrin. ${ }^{102}$ As with most anticholinergic agents, the reduction of acid secretion produced by pirenzepine is due to a decrease in the volume of gastric secretion rather than acid concentration. ${ }^{103}$ In normal control subjects, orally administered pirenzepine at doses of $50 \mathrm{mg}$ and $100 \mathrm{mg}$ reduced total nocturnal acid output by $32 \%$ and $41 \%$, respectively. ${ }^{104}$ One hour after a $50-\mathrm{mg}$ oral dose, basal gastric acid output was decreased by $71 \%$ and mealstimulated acid nutput was decreased by $51 \%$. Antisecretory activity is still decreased by approximately $45 \%$ at 4 hours after oral administration.

Intravenously administered pirenzepine has been demonstrated 
to produce modest decreases in the secretion of pancreatic enzymes such as trypsin, lipase, amylase, and chymotrypsin. In addition, a modest increase in bicarbonate secretion by the pancreas has been noted. Clinically significant alterations in pancreatic exocrine function have not been reported, however, nor have clinically important alterations in pancreatic endocrine function been observed. Pirenzepine does not appear to affect basal or postprandial concentrations of serum insulin or glucagon. In patients with duodenal ulcer, intravenous administration of pirenzepine reduces basal secretion of pancreatic polypeptide and decreases the rise in pancreatic polypeptide stimulated by sham feeding. ${ }^{105}$ Pirenzepine has minimal effects on serum gastrin concentrations. Intravenously administered single doses of pirenzepine have been reported to significantly decrease the volume of gastric mucous output, but the drug does not appear to alter the composition or function of the gastric mucous secretion. The clinical significance of these findings relating to gastric mucous is unknown. A dose-dependent decrease in pepsin output has also been reported following administration of intravenous pirenzepine.

When administered orally, therapeutic doses of pirenzepine do not increase heart rate significantly ${ }^{106}$ In patients with duodenal ulcers, a dose-related reduction in salivation has been noted when therapeutic doses of pirenzepine were administered intravenously. The effect was much less marked and of shorter duration than that occurring after equipotent doses of atropine ${ }^{80}$ Symptomatic drying of the mucous membranes is unusual, however. In a 4-day comparative trial, orally administered pirenzepine $50 \mathrm{mg}$ twice daily was associated with no ocular symptoms. ${ }^{106}$ Pirenzepine does not change intraocular pressure in subjects with open or closed angle glaucoma, and, unlike other classic antimuscarinic agents, pirenzepine is not contraindicated in patients with glaucoma. Despite the structural similarity of pirenzepine and tricyclic antidepressant drugs, pirenzepine does not cross the blood/brain barrier and has not been reported to exhibit central nervous system effects. ${ }^{10 \bar{r}, 108} \mathrm{Or}^{\mathrm{r}}$ ally administered pirenzepine has not been reported to affect residual urinary volume, tone of the bladder wall, or bladder emptying, even in patients with symptomatic prostatic hypertrophy. At usual therapeutic doses, oral pirenzepine does not slow gastric emptying of a liquid or solid meal in normal healthy subjects. ${ }^{107,109}$ Pirenzepine at 25 to $75 \mathrm{mg}$ daily has not been reported to have any significant effect on esophageal function in healthy subjects. ${ }^{110}$

With oral administration of the drug, peak plasma concentrations of pirenzepine are observed 2 to 3 hours after administration. The peak plasma concentration is linearly related to the dosage. ${ }^{111}$ With repeated oral doses in man, plasma concentrations have been reported to increase for the first few days, but remain constant there- 
after. No accumulation of the drug has been observed with longterm administration. The mean bioavailability of pirenzepine administered orally approximates $25 \% .{ }^{112,113}$ Bioavailability has been reported to decrease when the drug is taken with a meal.

Studies in animals have demonstrated that pirenzepine is distributed widely in the body, being found in all organs with the exception of the central nervous system. As mentioned previously, pirenzepine does not pass the blood/brain barrier. In addition, the drug does not appear to pass the placental barrier. No data are currently available regarding the excretion of pirenzepine into human breast milk.

Very little pirenzepine is metabolized. By 4 days after oral administration, $90 \%$ of the administered dose can be recovered in the feces; approximately $10 \%$ of the dose is excreted unchanged in the urine. ${ }^{113}$ Total plasma clearance approximates $250 \mathrm{cc} / \mathrm{min}$. The mean plasma half-life of pirenzepine is approximately 12 hours and is not influenced by the route of administration.

\section{CLINICAL USE}

Several studies have demonstrated that pirenzepine accelerates the healing of duodenal ulcers. The rate of ulcer healing in most studies is clearly dose-related. Ulcers have been reported to heal in $52 \%$ of patients treated with 50 to $75 \mathrm{mg}$ of pirenzepine daily, and in $70 \%$ of patients treated with 100 to $150 \mathrm{mg}$ per day. ${ }^{99}$ In a review by Carmine and Brogden, duodenal ulcers were noted to heal in $32 \%$ to $75 \%$ of patients taking placebos ${ }^{99}$ In similar studies, in $45 \%$ to $75 \%$ of those treated with less than $100 \mathrm{mg}$ /day of pirenzepine, ulcers were healed. However, in $70 \%$ to $90 \%$ of patients treated with pirenzepine 100 to $150 \mathrm{mg}$ /day over a 4-week period, ulcers were healed. These authors concluded that pirenzepine at doses of less than $100 \mathrm{mg} /$ day was ineffective in treating patients with acute peptic ulceration.

Numerous studies have compared relative efficacy of pirenzepine and cimetidine in the treatment of patients with acute ulceration. Most of these trials have not demonstrated a significant difference between the two agents in healing rates. Although results differ from author to author, within each study ulcer healing rates are generally similar following 4 or 6 weeks treatment with pirenzepine 100 to 150 $\mathrm{mg} /$ day or cimetidine $1,000 \mathrm{mg} /$ day. ${ }^{99}$ Although ultimate healing rates are similar for both drugs, symptomatic remission is usually faster in patients treated with cimetidine. Pirenzepine $100 \mathrm{mg}$ /day has also been demonstrated to be equivalent to ranitidine $300 \mathrm{mg} /$ day in the treatment of patients with acute peptic ulceration. ${ }^{114}$

Two studies have demonstrated that pirenzepine at a dose of 30 to $50 \mathrm{mg} /$ day was ineffective as chronic maintenance therapy. Re- 
lapse rate for patients receiving pirenzepine was not different from placebo-treated or untreated patients. Maintenance therapy with higher pirenzepine doses has not been reported.

Because of these considerations, the usual oral adult dose of pirenzepine for the treatment of patients with acute duodenal ulceration is $100 \mathrm{mg} /$ day in divided doses at bedtime and before the morning meal. The total daily dose may be increased to $150 \mathrm{mg} /$ day in two divided doses as needed. Pirenzepine may be combined with cimetidine or ranitidine, as this combination appears to potentiate the antisecretory effects of $\mathrm{H}_{2}$-receptor blockade. Anticholinergic therapy should be continued until ulcer healing occurs, as documented by repeat endoscopy at 4 to 8 weeks.

\section{SIDE EFFECTS}

In short-term control studies, pirenzepine has been demonstrated to be an effective and safe drug. Discontinuation, because of unpleasant side effects, is unusual and has occurred in approximately $2 \%$ of patients. ${ }^{99}$ The most frequently reported side effect of pirenzepine therapy is dry mouth. This symptom occurs in approximately $14 \%$ of patients receiving 100 to $150 \mathrm{mg} /$ day. The symptom is usually of mild-to-moderate severity and requires withdrawal of the drug in only $0.5 \%$ of treated patients. The incidence of dry mouth is clearly dose-dependent and decreasing dosage is usually followed by cessation of the unpleasant symptom.

Ocular disturbances, particularly blurred vision, are another antimuscarinic effect of pirenzepine experienced by approximately $1 \%$ of patients receiving $100 \mathrm{mg} /$ day. This side effect is also dose-dependent; $5.6 \%$ of patients taking $150 \mathrm{mg} /$ day will complain of blurred vision. ${ }^{115}$ The symptom is severe enough to require discontinuation in approximately $1 \%$ of patients at the higher dose range.

Clinically important effects on the gastrointestinal tract are unusual. In most instances, the relationship to the selective antimuscarinic action of pirenzepine is unclear. While $3.3 \%$ of patients complain of constipation, a similar $3.4 \%$ experience diarrhea during pirenzepine therapy. ${ }^{15}$ Only $0.5 \%$ of the patients required treatment stoppage because of adverse gastrointestinal effects. Central nervous system effects are unusual and rarely require termination of treatment. Other adverse effects, such as skin reactions, allergy, and nausea, are unusual. Cardiovascular side effects are rare. When pirenzepine 100 to $150 \mathrm{mg} /$ day and cimetidine $1,000 \mathrm{mg} /$ day were compared, the incidence of side effects such as headache, dizziness, endocrinologic abnormalities, allergic reactions, and central nervous system symptoms was slightly greater with a cimetidine group $;^{115}$ however, the relative incidence of dry mouth and blurred vision is clearly higher in patients receiving pirenzepine. Long-term studies 
in patients receiving pirenzepine have not reported any clinically significant adverse effects, nor have significant abnormalities in laboratory tests been reported in these patients. ${ }^{115}$

\section{CYTOPROTECTIVE AGENTS}

\section{PROSTAGLANDINS}

The term "cytoprotection" was coined by Jacobson ${ }^{116}$ and by Robert ${ }^{117}$ to denote the phenomenon by which the administration of prostaglandins confers gastric mucosa protection from ethanol, strong acids, strong alkali, or harmful physical agents. In the "cytoprotected" animals, the gastric mucosa remains remarkably intact after instillation of these agents which normally cause severe damage ${ }^{118}$ In the present context, "cytoprotection" is used to mean protection of the gastric mucosa from gross or histologic damage. An agent is said to have a cytoprotective effect if it protects against damage at doses that are lower than the threshold dose for inhibition of acid secretion. Prostaglandins are one of several classes of compounds with cytoprotective action (Table 3).

\section{Chemistry and Pharmacokinetics}

Prostaglandins are 20-carbon oxygenated fatty acids. They are synthesized from dietary essential fatty acids through the action of cyclooxygenase. This cyclooxygenase pathway also results in the synthesis of prostacyclin and thromboxanes (Fig 8). All the prostaglandins have a cyclopentane ring, and, depending on the structure of the ring, they are classitied as prostaglandin A, B, C, D, $\mathrm{E}$, and $\mathrm{F}$ (Fig 9). The compounds also have upper and lower carbon side-chains. Depending on the number of double-bonds present in the upper and lower side-chains, the prostaglandins are further designated 1,2, and 3 (Fig 10). The prostaglandins of medical interest

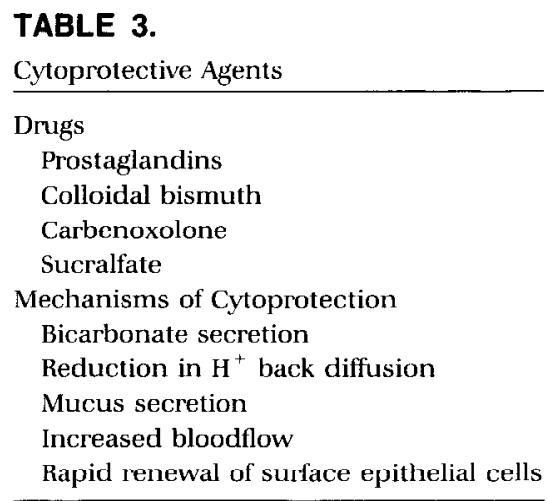




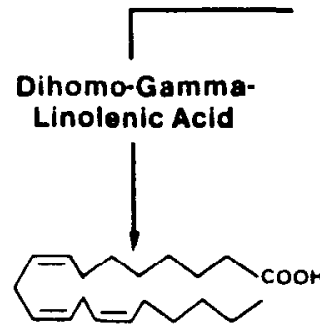

Elcosatrlenolc Acld (Omega-6-Futty Acld)

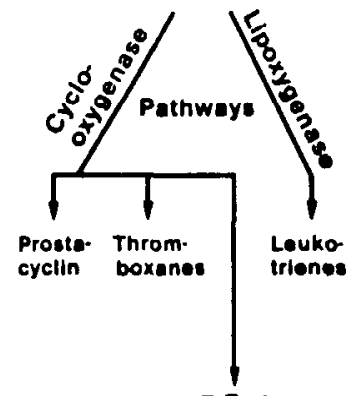

PG-1

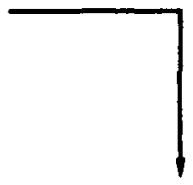

Arachidonlc Acid (20:4)

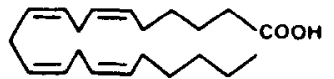

Elcosatetraenolc Acid (Omoga-6-Fatty Acid)

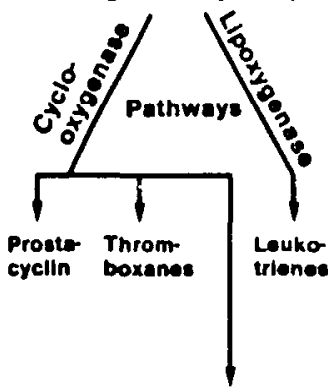

PG-2

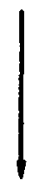

EPA (20:5)

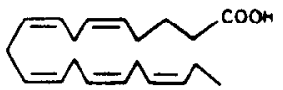

Elcosapentaenolc ACI (Omegn-3-Fatty Aclo)

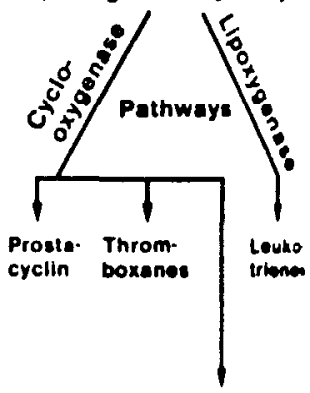

PG.3

Series

Series

\section{FIG 8.}

Major metabolic pathways of essential fatty acids and the synthesis of prostaglandins 1 , 2, and 3. (From Sontag SJ: Am J Gastroenterology 1986; 81:1021-1028. Used by permission.)

are of the E-type and the important molecules are prostaglandin E1 (PGE-1), PGE-2, and PGE-3. Analogues of PGE-1 and the naturally occurring PGE-2 have been developed for possible clinical use. To date, only three prostaglandin analogues have been subjected to double-blind controlled clinical trials. These are Misoprostil (G.D. Searle Co.), Enprostil (Syntex Corp.), and Orbaprostil (Upjohn Co.). Two mechanisms of action in healing ulcers are proposed for these drugs: (1) inhibition of acid secretion (antisecretory effect); and (2) cytoprotective effect which can occur at doses lower than the antisecretory dose. It appears that antisecretory doses are required to heal ulcers, although cytoprotective doses may protect against aspirin injury.

Naturally occurring prostaglandins have very short half-lives in the blood and are rapidly inactivated by enzymes in human tissue. The synthetic prostaglandin analogues resist rapid degradation and, when administered orally, are effective in inhibiting acid secretion 


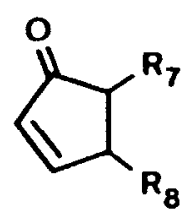

PGA

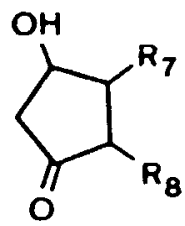

PGD<smiles>[R]C1=C([R6])C(=O)CC1</smiles>

PGB<smiles>[R8]C1C(=O)CC(O)C1[R7]</smiles>

PGE<smiles>[R8]C1=CCC(=O)C1[R7]</smiles>

PGC<smiles>[R6]C1C(O)CC(O)C1[R]</smiles>

PGF

\section{FIG 9.}

Prostaglandins are designated A through $F$ depending on the structure of the cycluperitrene ring of the molecule. Upper end lower side chains are represented by R7 7 carbons) and R8 (8 carbons). (From Sontag SJ: Am J Gastroenterology 1986; 81:1021-1028. Used by permission.)

stimulated by histamine, pentagastrin or food for up to 2 hours. Although their precise mechanism of action in inhibiting acid secretion is unknown, the compounds do not interact with the cell-surface receptors for histamine, gastrin, or acetylcholine. They also do not appear to interfere with the activity of the $\mathrm{H}^{+}-\mathrm{K}^{+}$ATPase.

\section{Clinical Use}

More than 3,000 patients in 20 countries have been enrolled in controlled ulcer trials of Misoprostil and Enprostil. ${ }^{119}$ Misoprostil, administered at a dose of $200 \mathrm{mg} 4$ times daily, causes endoscopic duodenal ulcer healing at 4 weeks in $63 \%$ of patients, compared to the healing rate for cimetidine of $72 \% .{ }^{120}$ In studies comparing Enprostil $(70 \mathrm{mg}$, twice daily), duodenal ulcer healing rates at 4 weeks were $40 \%$ for placebo, $75 \%$ for cimetidine, and $80 \%$ for Enprostil. ${ }^{121,122}$ In a European study, comparing Orbaprostil with placebo, the 4-week healing rates of duodenal ulcer were $67 \%$ and $40 \%$, respectively. ${ }^{123}$ Both Misoprostil and Enprostil have also been shown to heal over $80 \%$ of gastric ulcers in patients treated for 6 to 8 weeks. ${ }^{124,125}$

In erosive gastroduodenal disease, low doses of prostaglandins have been shown convincingly to prevent gastric mucosal damage and gastrointestinal blood loss in subjects receiving aspirin and nonsteroidal antiinflammatory drugs. ${ }^{126,127}$ 
<smiles>CCCCCCCCCC1C(=O)CC(O)C1/C=C/[C@H](O)CCCCC(=O)O</smiles>

PGE 1<smiles>CCCCCC(O)C=CC1C(O)CC(=O)C1CC=CCCCC(=O)O</smiles><smiles>CC/C=C\CC(O)/C=C/C1C(O)CC(=O)C1C/C=C/CCCC(=O)O</smiles>

PGE 3

FIG 10.

Prostaglandins 1,2 , and 3 are designated by the number of double bonds present in the upper and lower side chains. (From Sontag SJ: Am J Gastroenterology 1986; 81:10211028. Used by permission.)

The clinical applications and implications of prostaglandin therapy in patients with acid peptic disease are summarized in Table 4.

\section{Side Effects}

The major side effect of prostaglandin therapy is diarrhea. ${ }^{128}$ Some $30 \%$ to $40 \%$ of patients will experience some loosening of their stool but frank diarrhea occurs only in about 5\%. The diarrhea in most cases has been transient and has stopped despite continued administration of the drug. In less than $0.5 \%$ of patients, prostaglandin analogues have to be stopped because of severe diarrhea.

The other two side effects of prostaglandins are uterine bleeding and the potential for spontaneous abortions. In a West German 


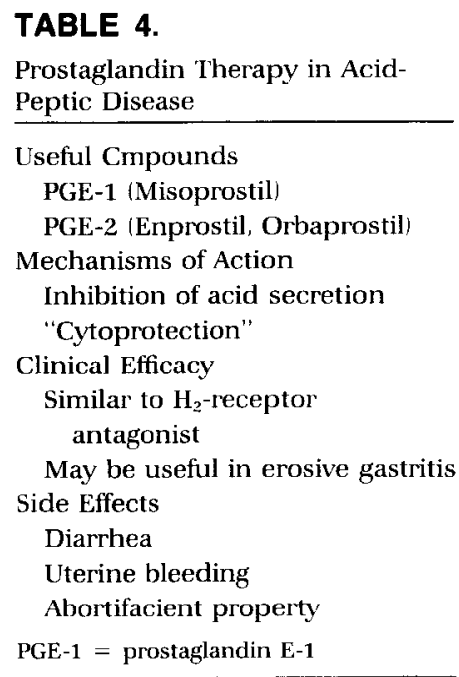

study in which 56 women received two $400-\mathrm{mg}$ doses of Misoprostil 5 hours apart on the evenings before a scheduled abortion, $6(11 \%)$ had partial or total abortion. ${ }^{129}$ This potential abortifacient property of prostaglandins is of major concern both in terms of danger to pregnant women and in terms of potential abuse by those wanting to terminate pregnancy.

\section{COATING AGENTS}

\section{Colloidal Bismuth Compounds}

Tripotassium dicitrate bismuthate, a colloidal bismuth compound, has been shown in rats to reduce the incidence of acute gastric ulcers induced by restraint, pyloric ligation, histamine, aspirin, or cortisone. ${ }^{130}$

\section{Chemistry and Mechanism of Actions}

Colloidal bismuth compounds promote healing by binding to protein and necrotic debris at the ulcer base to form a coating impermeable to acid. ${ }^{131}$ An acid medium is presumably required for colloidal bismuth to chelate to the protein components of the ulcer bed to create an insoluble coagulum. ${ }^{132}$ Both light and electron microscopy have shown an increase in the number of bismuth-laden macrophages recruited to the area of injury. The influx of these macrophages may expedite healing, and the microvilli of epithelial cells at the duodenal ulcer edge have been shown to return more quickly to their normal size in patients treated with bismuth as compared to patients treated with cimetidine. 
In addition to the protective coagulum which colloidal bismuth compounds form in the ulcer bed, other beneficial actions of these drugs have been cited. Tripotassium dicitratobismuthate has been shown to have antipepsin activity and to stimulate the release of gastric mucus. ${ }^{106}$

\section{Clinical Use}

Colloidal bismuth compounds are not approved for clinical use in the United States, and most of the reported trials are from the United Kingdom, Europe, Australia, and South Africa, where the compounds are in general use. In controlled clinical trials, colloidal bismuth compounds have been shown to cause healing rates comparable to cimetidine. ${ }^{133}$ The major difference between colloidal bismuth and cimetidine is the significantly lower ulcer recurrence rate after cessation of bismuth therapy relative to that observed of cessation of cimetidine. This observation suggests that colloidal bismuth may be capable of changing the natural history of duodenal ulcer disease in a manner not observed with cimetidine.

Both bictropeptide bismuthate ${ }^{134,135}$ and tripotassium dicitratobismuthate have been shown to heal gastric ulcers significantly better than placebo $179 \%$ to $90 \%$ vs. $30 \%$ to $35 \%$ at 4 weeks). While there is anticipation that colloidal bismuth may provide a more effective therapy of gastric ulcer than cimetidine, significantly large clinical trials are not available to sustain this assumption.

\section{Side Effects}

No serious side effects have been reported with the use of colloidal bismuth compounds. However, bismuth causes blackening of the stools which may be confused with melena. It also causes the tongue to turn black. Although innocuous, this side effect is cosmetically unappealing.

\section{SUCRALFATE}

\section{Chemistry and Mechanism of Actions}

Sucralfate is the basic aluminum salt of sulfated sucrose. In the acid medium of the stomach, it becomes viscous and adheres to defective mucosa to form a protective barrier. ${ }^{136}$ Thus, the ulcer bed becomes protected from continuing exposure to acid and pepsin. In addition to this barrier action, sucralfate possesses several potentially beneficial actions: (1) it neutralizes small amounts of acid ( $1 \mathrm{gm}$ of sucralfate buffers $13 \mathrm{mEq}$ of $\mathrm{H}^{+}$at $\mathrm{pH} 4.0$ ); (2) it inhibits the action of pepsin; (3) it binds bile-salts, leading to their depletion from the gastric lumen; (4) it stimulates mucus secretion. Sucralfate is one of the drugs said to have "cytoprotective" properties. Whether this property is due solely to these listed actions of the drug, or whether 
it also has additional effects on the rate of renewal of surface epithelial cells and prostaglandin synthesis, has not been conclusively shown.

\section{Clinical Use}

Sucralfate is the first cytoprotective drug commercially available in the United States for the treatment of ulcer. Several studies have shown sucralfate therapy to be efficacious in the treatment of duodenal ulcer. ${ }^{137}$ Sucralfate has been demonstrated to heal gastric ulcers better than placebo $150 \%$ to $71 \%$ vs. $13 \%$ to $40 \%$ at 4 weeks ${ }^{138.139}$ Sucralfate therapy has also been shown to be effective in preventing gastric ulcer relapse.

Sucralfate has been reported to protect against gastric mucosal injury by aspirin ${ }^{1+2}$ ethanol ${ }^{1+3}$ and concentrated acid or concentrated alkali. ${ }^{144}$ In addition, sucralfate has been shown to be as effective as antacids in the prevention of stress ulceration in critically ill patients. ${ }^{1+5}$ The drug has also been used with reported efficacy in reflux esophagitis and gastritis.

\section{Side Effects}

Side effects are mild and infrequent with the use of sucralfate, occurring in less than $5 \%$ of patients. The reported side effects include constipation, dizziness, dry mouth, skin rash, headache, diarrhea, nausea, and abdominal discomfort. This safety factor makes sucralfate attractive to medical practitioners for long-term maintenance use. ${ }^{146}$

\section{A PERSPECTIVE OF THE IMPACT OF ULCER DRUGS ON ULCER SURGERY}

A major decline has occurred in the incidence of surgery for peptic ulcer disease. Two factors are responsible: a decrease in the incidence of peptic ulcer disease itself and the introduction of effective pharmacologic agents. Of these two factors, the latter has had the more significant effect on ulcer surgery, with the decline almost entirely in elective ulcer surgery. It is only on rare occasions now that patients are referred to surgery because of intractability of the disease. While elective operations have declined, the number of operations performed for complications of peptic ulcer (perforation, bleeding, and obstruction) has remained relatively stable. Many surgeons feel the type of peptic ulcer they are now called on to treat operatively is more virulent, with a higher incidence of giant ulcers, more severe duodenal deformity, and more extensive penetration and inflammation. This clinical impression, however, remains only an impression, and there are no clinical studies to support it. The challenge for surgeons has now become to mesh the currently avail- 
able operative therapies to the widening array of effective pharmacologic agents.

From the patient's perspective, the most important issue is pain control. The currently available $\mathrm{H}_{2}$-receptor antagonists and newer agents such as omeprazole are able to provide relief of pain in the large majority of patients $(70 \%-90 \%)$ within 2 to 4 weeks of initiation of treatment. Symptomatic control does not seem to be compromised by a history of recurrence. Relief of pain should not be equated with complete healing of ulceration, however, nor does absence of pain eliminate the possibility of complication of ulcer disease.

A high proportion of ulcer patients who bleed do so during a recurrence, and patients who have bled once have a higher risk of bleeding again. Boyd and colleagues have estimated that the lifetime risk of hemorrhage for duodenal ulcer patients who have not had surgery and who do not receive maintenance drug therapy approximates $39 \%$ for men and $36 \%$ for women. ${ }^{147}$ In contrast, the overall proportion of recurrent ulcers that bleed during maintenance therapy is approximately $2 \%$ during the first year. ${ }^{148}$ Thus a strong argument can be made, from the standpoint of hemorrhage, for continued maintenance drug therapy after initial healing of ulcers. Recurrent ulcer hemorrhage of a degree that requires hospitalization, or transfusion, or active endoscopic treatment should be considered an indication for operation. Of course, massive hemorrhage should always prompt consideration for operative intervention.

Although perforation is less common than hemorrhage, the rate of perforation has not decreased markedly since the introduction of effective $\mathrm{H}_{2}$-receptor therapy. The lifetime risk of perforation for untreated patients approximates $10 \% .{ }^{14 \tau}$ Ulcer perforation appears to be rare during maintenance therapy for individuals without a history of antecedent perforation. However, perforation remains an indication for definitive anti-ulcer surgery for those patients with historical or anatomic evidence of chronic peptic ulcer disease.

The reported incidence of symptomatic pyloric stenosis is variable, but may approximate $10 \%$ in untreated individuals. None of the agents reviewed can be expected to have beneficial effect on the chronic cicatrization causing pyloric obstruction. Pyloric stenosis remains a firm indication for operative intervention.

With the decline of peptic ulcer surgery, surgical residents have less opportunity to learn all the details of vagotomy or gastric resection. The introduction of proximal gastric vagotomy in the treatment of duodenal ulcer coincided with the sharp decline in ulcer surgery. As a result, many surgical residents complete their training without a broad exposure to anti-ulcer surgery. As mentioned previously, the major effect of the advent of potent ulcer drugs has been on elective and not emergency operations for the disease. It is possible that this, 
too, may change in the future. As better and safer cytoprotective drugs are discovered, the natural history of peptic ulcer in individual patients treated will be altered. Such drugs also may be more efficacious in maintenance therapy. Both of these factors may contribute to lowering the incidence of complications in peptic ulcer disease and, hence, emergent surgery for peptic ulcer.

\section{REFERENCES}

1. Debas IIT: Peripheral regulation of gastric acid secretion, in Johnson LR (ed): Physiology of the Gastrointestinal Tract. New York, Raven Press, 1987, pp 931-946.

2. Debas HT, Mulholland MW: New horizons in the pharmacologic management of peptic ulceration. Am J Surg 1986; 151:422-430.

3. Mendeloff A: What has been happening to duodenal ulcer? Gastroenterologv 1974; 67:1020-1022.

4. Price WA, Grizzle JA, Postlewait RW, et al: Results of operation for duodenal ulcer. Surg Gynecol Obstet 1970; 131:233-244.

5. Monson RR, McMahon B: Peptic ulcer in Massachusetts physicians. $N$ Engl $J$ Med 1969; 281:11-15.

6. Elashoff JD, Grossman MI: Trends in hospital admissions and death rates for peptic ulcer in the United States from 1970 to 1978. Gastroenterology $1980 ; 78: 280-285$.

7. Kurata JH, Honda GD, Frankl H: Hospitalization and mortality rates for peptic ulcers: A comparison of a large health maintenance organization and United States data. Gastroenterology 1982; 83:1008-1016.

8. Sontag S, Graham DY, Belisto $A$, et al: Cimetidine, cigarette smoking, and recurrence of duodenal ulcer. $N$ Engl J Med 1984; 311:689-693.

9. Friedman GD, Siegelaub AB, Seltzer CC: Cigarettes, alcohol, coffee, and peptic ulcer. $N$ Engl $J$ Med 1974; 290:469-473.

10. Fineberg HV, Pearlman LA: Surgical treatment of peptic ulcer in the United States: Treatments before and after the introduction of cimetidine. Lancet $1981 ; 1: 1305-1307$.

11. Coggon D, Lambert $P$, Langman MJS: Twenty years of hospital admissions for peptic ulcer in England and Wales. Lancet 1981; 1:1302-1304.

12. Isenberg JI, Grossman MI, Maxwell V: Increased sensitivity to stimulation of acid secretion by pentagastrin in duodenal ulcer. $J$ Clin Invest 1975; $55: 330-337$.

13. Gledhill T, Howard OM, Buck M, et al: Single nocturnal dose of $\mathrm{H}_{2}$ receptor antagonist for the treatment of duodenal ulcer. Gut $1983 ; 23: 904-908$.

14. Grossman MI: Pcptic Ulcer: A Guide for the Practicing Phvsician. Chicago, Year Book Medical Publishers, Inc, 1981, p 44.

15. Baron JH: Current views of pathogenesis of peptic ulcer. Scand J Gastroenterol [Suppl] 1982; 17:7-20.

16. Grossman MI: Physiological abnormalities in duodenal ulcer: A brief review. Brain Res Bull 1980; 5:37-38.

17. Lam SK, Isenberg JI, Grossman MI, et al: Rapid gastric emptying in duodenal ulcer patients. Dig Dis Sci 1982; 27:598-604.

18. McCloy RF, Greenberg GR, Baron JH: Duodenal $\mathrm{pH}$ in health and duodenal ulcer disease. Gut $1984 ; 25: 386-392$.

19. Malagelada JR, Lonstreth GF, Deering TB: Gastric secretion and emptying after ordinary meals in duodenal ulcer. Gastroenterologv 1977; 73:989-994. 
20. Konturek SJ, Swierczek J, Kwiecien N, et al: Effect of somatostatin on mealinduced gastric secretion in duodenal ulceration. $B r J$ Surg 1978; 65:793796.

21. Chayvialle JA, Descus F, Bernard C, et al: Sonnalustatin in mucusa of stumach and duodenum in gastroduodenal disease. Gastroenterology 1978; 75:13-19.

22. Robert A: Cytoprotection by prostaglandins. Gastroenterology 1979; 77:761767.

23. Rachmilewitz D, Ligumsky M, Fich $A$, et al: Role of endogenous gastric prostanoids in the pathogenesis and therapy of duodenal ulcer. Gastroenterology 1986; 90:963-969.

24. Isenberg JI, Selling JA, Hogan DL, et al: Impaired proximal duodenal mucosal bicarbonate secretion in patients with duodenal ulcer. $N$ Engl $J$ Med 1987; 316:374-379.

25. Blair AJ, Richardson CT, Vasko $M$, et al: Comparison of acid secretory responsiveness to gastrin heptadecapeptide and of gastrin heptadecapeptide pharmacokinetics in duodenal ulcer patients and nomal subjects. J Clin Invest 1986; 78:779-783.

26. McGuigan JE: Side effects of histamine 2-receptor antagonists. Clin Gastroenterol 1981; 12:819-838.

27. Funder JW, Mercer JE: Cimetidine: Histamine $\mathrm{H}_{2}$ receptor antagonist occupies androgen receptors. $J$ Clin Endocrinol Metab 1979; 48:189-191.

28. Rendic S, Sunjic B, Toso R, et al: Interaction of cimetidine with liver microsomes. Xenobiotica 1979; 9:555.

29. Peden NR, Robertson AJ, Boyd EGS: Mitogen stimulation of peripheral blood lymphocytes of duodenal ulcer patients during treatment with cimetidine or ranitidine. Gut $1982 ; 23: 398-403$.

30. Smith IR, Cleverby MT, Gancllin CR, et al: Binding of ${ }^{3} \mathrm{H}$-cimetidine to rat brain tissues. Agents Actions 1980; 10:422-426.

31. Lakoski JM, Aghajanian GK, Gallager DW: Interaction of histamine $\mathrm{H}_{2}$ receptor antagonists with GABA and benzodiazepine binding sites in the central nervous system. Eur $J$ Pharmacol 1983; 88:241-245.

32. Lebert PA, Mahon WA, MacLeod SM, et al: Ranitidine kinetics and dynamics: II. Intravenous dose studies and comparison with cimetidine. Clin Pharmacol Ther 1981; 30:545-550.

33. McNeil JJ, Mihaly GW, Anderson A, et al: Pharmacokinetics of the $\mathrm{H}_{2}$ receptor antagonists ranitidine in man. Br J Clin Pharmacol 1981; 12:411-415.

34. Brogden RN, Carmine AA, Heel RC, et al: Ranitidine: A review of its pharmacology and therapeutic use in peptic ulcer disease and other allied diseases. Drugs 1982; 24:267-303.

35. Peden NR, Richards DA, Saunders JHB, et al: Pharmacologically effective plasma concentration of ranitidine. Lancet 1979; 2:199-200.

36. Lebert PA, MacLeod SM, Mahon WA, et al: Ranitidine kinetics and dynamics: I. Oral dose studies. Clin Pharmacol Ther 1981; 30:539-544.

37. Burland WL. Duncan WAM. Hesselbo T, et al: Pharmacological evaluation of cimetidine-A new $\mathrm{H}_{2}$ histamine receptor antagonist in healthy man. $\mathrm{Br}$ $J$ Clin Pharmacol 1975; $2: 481$.

38. Gugler R, Fuchs G, Dieckmanm N, et al: Cimetidine plasma concentrations-Kesponse relationship. Clin Pharmacol Ther 1981; 29:744-748.

39. Ostro MJ: Pharmacodynamics and pharmacokinetics of parenteral histamine $\left(\mathrm{H}_{2}\right)$-receptor antagonists. $A m J$ Med 1987; 83(suppl 6A):15-22.

40. Ostro MJ, Russell JA, Soldin SJ, et al: Control of gastric $\mathrm{pH}$ with cimetidine: Boluses versus primed infusion. Gastroenterology 1985; 89:532-537. 
41. Debas HT, Mulholland MW: New horizons in the pharmacological management of peptic ulceration. Am J Surg 1986; 151:422-430.

42. McMillan MA, Amelis D, Siegel JH: Cimetidine and mental confusion. $N$ Engl J Med 1978; 298:284-285.

43. Kimelblatt BJ, Cerra FB, Calleri G: Dose and serum concentration relationships in cimetidine-associated mental confusion. Gastroenterologv 1980; 78:791-795.

44. Adler AE, Sadja L, Wilets G: Cimetidine toxicity manifested as paranoia and hallucinations. Am J Psychiatry 1980; 137:1112-1113.

45. Schentag JJ, Cerra FB, Colleri G: Pharmacokinetic and clinical studies in patients with cimetidine-associated mental confusion. Lancet 1979; 1:177181.

46. Jorizzo JL, Sams $W M \quad J r$, Jegasothy $B B$, et al: Cimetidine as an immunomodulator: Chronic mucocutaneous candidiasis as a model. Ann Intern Med 1980; 92:192-195.

47. Zeldis JB, Friedman LS, Isselbacher KG: Ranitidine: A new $\mathbf{H}_{2}$ receptor antagonist. $N$ Engl J Med 1980; 309:1368-1373.

48. Freston JW: Cimetidine and agranulocytosis. Ann Intern Med 1979; 90:264265.

49. Hertzel DJ, Bochner F, Hallpike JF, et al: Cimetidine in interaction with phenytoin. Br Med J 1981; 292:512.

50. Klotz U, Reimann I: Delayed clearance of diazepam due to cimetidine. $N$ Engl J Med 1980; 302:1012-1014.

51. Kirch $\mathrm{K}$, Aadland $\mathrm{E}$, Berstead $\mathrm{A}$ : Inhibition of gastric secretion in man with a new $\mathrm{H}_{2}$ receptor antagonist ranitidine. Scand $J$ Gastroenterol 1980; 15:249-251.

52. Breen KG, Bury R, Desmond PV, et al: Effects of cimetidine and ranitidine on hepatic drug metabolism. Clin Pharmacol Ther 1982; 31:297 300.

53. Roberts RK, Grice J, Wood L, et al: Cimetidine impairs the elimination of theophylline and antipyrine. Gastroenterology 1981; 81:19-21.

54. Desmond PV, Patwhardhan RV, Schenker S, et al: Cimetidine impairs the elimination of chlordiazepoxide (Librium) in man. Ann Intern Med 1980; 93:266-268.

55. Feely J, Wilkinson GR, Wood AJJ: Reduction of liver blood flow and propanolol metabolism by cimetidine. $N$ Engl $J$ Med 1981; 304:692-695.

56. Feely J, Guy B: Ranitidine also reduces liver blood flow. Lancet 1982; $1: 169$.

57. Carlson HE, Ippoliti AF: Cimetidine, an $\mathrm{H}_{2}$-antihistamine stimulates prolactin secretion in man. $J$ Clin Endocrinol 1977; 45:367-370.

58. McGuigan JE: Side-effects of histamine 2-receptor antagonists. Clin Gastroenterol 1981; 12:819-838.

59. Smith JL, Gannal MA, Chremos AN, et al: Fannulidine, a new $\mathrm{H}_{2}$ receptor antagonist. Dig Dis Sci 1985; 30:308-312.

60. McCallum RW, Chremos AN, Kuljian B, et al: MK-208, a novel histamine $\mathrm{H}_{2}$ receptor inhibitor with prolonged antisecretory effects. Dig Dis Sci 1985; 30:1139-1144.

61. Klotz U, Arvela P, Rosenkranz B: Famotidine, a new $\mathrm{H}_{2}$ receptor antagonist, does not affect hepatic elimination of diazepam or tubular secretion of procainamide. Eur J Clin Pharmacol 1985; 28:671-675.

62. Rohner HG, Gugler R: Treatment of active duodenal ulcers with famotidine: A double-blind comparison with ranitidine. Am J Med 1986; 81(suppl 4B):13-16

63. McCullough AR: A multicenter randomized double-blind study comparing 
famotidine with ranitidine in the treatment of active duodenal ulcer disease. Am J Med 1986; 81(suppl 4B):17-24.

64. Simon B, Dammann HG, Jakob G, et al: Famotidine versus ranitidine for the short-term treatment of duodenal ulcer. Digestion 1985; 32(suppl 1):32-37.

65. Texter EC, Navab F, Mantell G, et al: Maintenance therapy of duodenal ulcer with famotidine: A multicenter United States study. Am J Med 1986; 81(suppl 4B):25-32.

66. Cavanagh RL, Usakewicz JJ, Byniski JP: Comparative activities of three new histamine $\mathrm{H}_{2}$-receptor antagonists. Fed Proc 1980; 39:768.

67. Brater DC, Meyers WM Jr, Dandekar KA, et al: Clinical pharmacology of etintidine in patients with duodenal ulcer. Eur $J$ Clin Pharmacol 1982; 23:495-500.

68. Fellenius E, Elander B, Wallmark B, et al: Inhibition of acid secretion from isolated gastric glands by substituted benzimidazoles. Am J Physiol 1982: 243:G505-G510.

69. Lind T, Cederberg C, Ekenbed G, et al: Effects of omeprazole, a gastric proton pump inhibitor, on pentagastrin stimulated acid secretion in man. Gut $1983 ; 24: 270-276$.

70. Londong $W$, Londong $V$, Cederberg $C$, et al: Dose-response study of omeprazole on meal-stimulated gastric acid secretion and gastrin release. Gastroenterology $1983 ; 85: 1375-1378$.

71. Brandstrom A, Lindberg P, Junggren U: Structure activity relationships of substituted benzimidazoles. Scand J Gastroenterol [Suppl] 1985; 20:15-22.

72. Howden CW, Forrest JAH, Reid JL: Effects of single and repeated doses of omeprazole on gastric acid and pepsin secretion in man. Gut 1984; 25:707710.

73. Kittang E, Aadland E, Schjonsby H: Effect of omeprazole on the secretion of intrinsic factor gastric acid and pepsin in man. Gut 1985; 26:594-598.

74. Festin HPM, Thijs JC, Lamers CB, et al: Effect of oral omeprazole on serum gastrin and serum pepsinogen I levels. Gastroenterology 1984; 85:10301034.

75. Horowitz M, Hetzel DJ, Buckle PJ, et al: The effects of omeprazole on gastric emptying in patients with duodenal ulcer disease. $\mathrm{Br} J$ Clin Pharmacol $1984 ; 18: 791-794$.

76. Cederberg $\mathrm{C}$, Lind $\mathrm{T}$, Axclson $\mathrm{M}$, et al: Long-term acid inhibitory effect of different daily doses of omeprazole 24 hours after dosing. Gastroenterology 1984; 86:1043.

77. Sharma BK, Santana IA, Walt RP, et al: Intragastric acidity after treatment with omeprazole. Gut 1983; 24:A973.

78. Prichard PJ, Yeomens ND, Mihaly GW, et al: Omeprazole: A study of its inhibition of gastric $\mathrm{pH}$ and oral pharmacokinetics after morning or evening doses. Gastroenterology 1985; 88:64-69.

79. Muller P, Dammann HG, Simon B: Human acid secretion during and after 18 days' treatment with omeprazole. Ital $J$ Gastroenterol 1985; 17:96-97.

80. Lind T, Cederbert $C$, Ekenbed $G$, et al: Effects of omeprazole--a gastric proton pump inhibitor-on pentagastrin stimulated acid secretion in man. Gut 1983; 24:270-276.

81. Clissold SP. Campoli-Richards DM: Omeprazole: A preliminary review of its pharmacodynamics and pharmacokinetic properties and therapeutic potential in peptic ulcer disease and Zollinger-Ellison syndrome. Drugs 1986; 32:15-47.

82. Pilbrant A. Cecierberg C: Development of an oral formulation of omeprazole. Scand J Gastroenterol [Suppl] 1985; 20:113-120. 
83. Regardh CG, Galbrelsson M, Hoffman KJ, et al: Pharmacokinetics and metabolism of omeprazole in animals and man-An overview. Scand $J$ Gastroenterol [Suppl] 1985; 20:79-94.

84. Larsson H, Mattsson H, Sundell G, et al: Animal pharmacodynamics of omeprazole. Scand J Gastroenterol [Suppl] 1985; 20:23-36.

85. Naesdal J, Lind T, Bergsaker-Aspoy J, et al: The rate of healing of duodenal ulcers during omeprazole treatment. Scand J Gastroenterol 1985; 20:691695.

86. Walan A, Bergsaker-Aspoy J, Farup PG, et al: Four week study of the rate of duodenal ulcer healing with omeprazole. Gut 1983; 24:A972.

87. Tytgat GNJ, Lemers CB, Wilson JAN, et al: One hundred percent healing with omeprazole in peptic ulcers resistant to histamine $\mathrm{H}_{2}$ receptor antagonists. Gastroenterology 1985; 88:16-22.

88. Lauritsen K, Rune SJ, Bytzer P, et al: The effect of omeprazole and cimetidine on duodenal ulcer. $N$ Engl $J$ Med 1985; 312:958-961.

89. Walan A, Bardhan KD, Bianchi-Porro G, et al: A comparison of two different doses of omeprazole vs. ranitidine in duodenal ulcer healing. Gastroenterologv 1985; 88:16-25.

90. Gugler R, Jensen JC: Omeprazole inhibits elimination of diazepam. Lancet 1984; $1: 969$.

91. Henry DA, Somerville KW, Kitchingman G, et al: Omeprazole: Effects on hepatic oxidase drug metabolism. J Clin Pharmacol 1984; 18:195-200.

92. Ekman L, Hansson E, Havu N, et al: Toxicological studies on omeprazole. Scand J Gastroenterol [Suppl] 1985; 20:53-69.

93. Larsson $H$, Carlsson $E$, Hakansson $R$, et al: Relation of plasma gastrin concentration in oxyntic mucosal ECL density during inhibition of gastric secretion in the rat. Gut $1985 ; 26: A 558$.

94. Larsson $\mathrm{H}$, Carlsson $\mathrm{E}$, Mattsson $\mathrm{H}$, et al: Plasma gastrin and gastric enterochromaffinlike cell activation and proliferation. Gastroenterology 1986; 90:391-399.

95. Sharma BK, Santana IA, Wood EC, et al: Intragastric bacterial and nitrosation before, during, and after treatment with omeprazole. $\mathrm{Br}$ Med $J$ 1984; 289:717-719.

96. Hammer R, Berrie CP, Birdsall NJM, et al: Pirenzepine distinguishes between different subclasses of muscarinic receptors. Nature 1982; 2:900-902.

97. Hirschowitz BI, Fong J, Molina E: Effects of pirenzepine and atropine on vagal and cholinergic gastric secretion and gastrin release and on heart rate in the dog. J Pharmacol Exp Ther 1983; 225:263-268.

98. Biachi-Porro G, Prada A, Parente F, et al: The effects of pirenzepine on meal-stimulated gastric acid secretion, gastrin release and gastric emptying. Scand J Gastroenterol [Suppl] 1981; 17:159-162.

99. Carnine AA, Brodgen RN: Pirenzepine: A review of its pharmacodynanic and pharmacokinetic properties and therapeutic efficacy in peptic ulcer disease and other allied diseases. Drugs 1985; 30:85-126.

100. Stockbrugger RW, Jaup BA, Dotevall G: The effect of different doses of pirenzepine on gastric secretion stimulated by modified sham feeding in man. Scand J Gastroenterol [Suppl] 1982; 17:111-117.

101. Jain AK, LaCorte $W$, Haugue D, et al: Gastric antisecretory activity of LS-519: A controlled study. Clin Pharmacol Ther 1979; 25:231.

102. Eugenides $N$, Stockbrugger RW, Hobsley $M$, et al: Effect of two doses of pirenzepine on histamine-stimulated gastric acid secretion in man. Scand J Gastroenterol [Suppl] 1982; 17:125-129.

103. Fritsch WP, Schacht U, Scholten T, et al: Effects of cimetidine and piren- 
zepine on perioperative electrical vagal stimulation of gastric acid secretion. Scand J Gastroenterol [Suppl] 1980; 15:95-100.

104. Dammann HG, Simon B, Muller P, et al: Inhibition of nocturnal acid secretion by pirenzepine. Arzneimittel-forschung 1982; 32:300-310.

105. Konturek SJ, Obtulowicz W, Kwiewcien N, et al: Effects of pirenzepine and atropine on gastric secretory and plasma hormonal responses to sham feeding in patients with duodenal ulcer. Scand $J$ Gastroenterol [Suppl] 1980: 15:63-69.

106. Jaup BH, Dotevall G: The effect of pirenzepine and L-hyoscyamine on gastric emptying and salivary secretion in healthy volunteers. Scand $J$ Gastroenterol 1981; 16:769-773.

107. Jaup BH, Blomstrand C: Cerebro-spinal fluid concentrations of pirenzepine after therapeutic dosage. Scand J Gastroenterol [Suppl] 1980; 15:35-37.

108. Kuhn E, Honzak R: Psychometric studies of pirenzepine. Scand .I Gastroenterol [Suppl] 1980; 15:47-53.

109. Stacher $G$, Havlik $E$, Bergmann $H$, et al: Effects of oral pirenzepine on gastric emptying and antral motor activity in healthy man. Scand $J$ Gastroenterol [Suppl] 1982; 17:153-158.

110. Dent J: Muscarinic receptors in esophageal motor functions. Trends Pharmacol Sci 1984; (Jan suppl):82.

111. Ohashi $\mathbf{I}$, Otani $M$, Kohei $H$ : The plasma level and urinary excretion of pirenzepine dihydrochloride (LS 519) in man. Jpn J Clin Pharmacol Ther 1980; 11:153-159.

112. Hammer R, Koss FW: The pharmacokinetic profile of pirenzepine. Scand $J$ Gastroenterol [Suppl] 1979; 14:1-6.

113. Hammer R, Bozler G, Zimmer A, et al: Pharmacokinetics and metabolism of gastrozepin in man. Therapiewoche 1977; 27:1575-1593.

114. Giacosa A, Cheli R, Molinari F, et al: Comparison between ranitidine, ci metidine, pirenzepine and placebo in the short-term treatment of duodenal ulcer. Scand $J$ Gastroenterol [Suppl] 1982; 17:215-219.

115. Giorgi-Conciato M, Daniotti S, Ferrari PA, et al: Efficacy and safety of pirenzepine in peptic ulcer and non-ulcerous gastroduodenal diseases. A multicenter control clinical trial. Scand J Gastroenterol [Suppl] 1982; 17:1-42.

116. Jacobson ED, Chaudhury TK, Thompson WJ: Mechanism of gastric mucosal cytoprotection by prostaglandins. Gastroenterology 1976; 70:A897.

117. Robert A: Cytoprotection by prostaglandins. Gastroenterology 1979; 77:761767.

118. Ito S, Lacy ER: Morphology of rat gastric mucosal damage, defense and restitution in the presence of luminal ethanol. Gastroenterology 1985; $88: 250-260$.

119. Sontag SJ: Prostaglandins and acid peptic disease. Am J Gastroenterol 1986; 81:1021-1028.

120. Nicholson, PA: A multicenter international controlled comparison of two dosage regimens of misoprostil and cimetidine in the treatment of duodenal ulcer in outpatients. Dig Dis Sci 1985; 30(suppl):171-177.

121. Thomson ABR, Navert $H$, Halvorsen $L$, et al: Comparison of enprostil and placebo in active duodenal ulcer. Am J Med 1986; 81(suppl):59-63.

122. Vantreppen G, Janssens J, Popiela T, et al: Effects of 15(R)-15 methyl prostaglandin $\mathrm{E}_{2}$ (orbaprostil) on the healing of duodenal ulcer: $A$ double-blind multicenter study. Gastroenterology 1988; 83:357-363.

123. Winters L: Comparison of enprostil and cimetidine in active duodenal ulcer: Summary of pooled European studies. Protective and therapeutic effects of gastrointestinal prostaglandins. Am $J$ Med 1986; 8(suppl):69-74. 
124. Rachmilewitz D, Chapman JW, Nicholson PA: A multicenter international controlled comparison of two dosage regimens of misoprostil with cimetidine in the treatment of gastric ulcer in outpatients. Dig Dis Sci 1986; 31/suppl):75-80.

125. Navert $H$, Thomson ABR, Archambault $A$, et al: Treatment of gastric ulcer with enprostil. Am $J$ Med 1986; 81(suppl):80-84.

126. Gilbert DA, Surawicz CM, Silverstein FE, et al: Prevention of acute aspirininduced gastric mucosal injury by 15-R-15 methyl prostaglandin E2: An endoscopic study. Gastroenterology 1984; 867:339-345.

127. Cohen MM, McCreary D, Clark K, et al: Protection against aspirin-induced antral and duodenal damage with enprostil. A double-blind endoscopic study. Gastroenterology 1985; 88:382-386.

128. Hertin RL, Clay GA: Overview of clinical safety with misoprostil. Dig Dis Sci 1985; 30(suppl):185-193.

129. Lewis J: FDA GI advisory committee summary. Am J Gastroenterol 1985; $80: 743-745$.

130. Koo J, Ho J, Lam S, et al: Selective coating of gastric ulcer by tripotassium dicitrato bismuthate in the rat. Gastroenterologv 1982; 82:646670.

131. Brogden RN, Pinder RN, Sawyer PR: Tri-potassium di-citrato-bismuthate: A report on its pharmacological properties and therapeutic efficacy in peptic ulcer. Drugs 1976; 121:401-411.

132. Wilson TR: The pharmacology of tripotassium-dicitrato-bismuthate (TDB). Postgrad Med J 1975; (suppl 5):18-21.

133. Martin DF, Hollander D, May SJ: Differences in relapse rates of duodenal ulcer after healing with cimetidine or tri-potassium di-citrato-bismuthate. Lancet 1981; 1:7-10.

134. Moshal MG: A double blind gastroscopic study of bismuth-peptic complex in gastric ulceration. $S$ Afr Med $J$ 1974; 48:1610-1611.

135. Lee SP, Nicholson GI: Increased healing of gastric and duodenal ulcers in a controlled trial using tri-potassium di-citrato-bismuthate. Med $J$ Aust $1977 ; 1: 808-812$.

136. Nagashima R: Mechanism of action of sucralfate. $J$ Clin Gastroenterol 1981; 3(suppl 2):117-127.

137. McHardy GG: A multicenter double-blind trial of sucralfate and placebo in duodenal ulcer. $J$ Clin Gastroenterol 1981; 3(suppl 2):147-152.

138. Rhodes J, Mayberry JF, William RA, et al: Clinical trial of sucralfate in the treatment of gastric ulcer, in Caspary WF (ed): Duodenal Ulcer, Gastric Ulcer, Sucralfate: A New Therapeutic Concept. Munich, Urban and Schwanzenberg, 1981, pp 101-104.

139. Fixa B, Komarova $O$ : Aluminum sucrose sulfate (sucralfate) in the treatment of peptic ulcer (double-blind study), in Caspary $W \mathbf{F}$ (ed): Uuodenal Ulcer, Gastric Ulcer, Sucralfate: A New Therapeutic Concept. Munich, Urban and Schwanzenberg, 1981, pp 80-84.

140. Marks IN, Luke $W$, Wright JP, et al: Ulcer healing and relapse rates after initial treatment with cimetidine or sucralfate. J Clin Gastroenterol 1981; 3(suppl 2):163-165.

141. Miyake T, Ariyoshi J, Suzak T, et al: Endoscopic evaluation of the effect of sucralfate therapy and other clinical parameters on the recurrence rate of gastric ulcers. Dig Dis Sci 1980; 25:1-7.

142. Tesler MA, Lim ES: Protection of gastric mucosa by sucralfate from aspirininduced erosions. $J$ Clin Gastroentcrol 1981; 3(suppl 2):175-179.

143. Hollander D, Tarnawski A, Gergely H, et al: Sucralfate protection of gastric 
mucosa against alcohol induced necrosis: A prostaglandin mediated process? Gastroenterology 1983; 84:1190.

144. Ligumsky M, Karmeli $F$, Rachmilewitz D: Sucralfate stimulation of gastric PGE2 synthesis-Pussible mechanism to explain its effective cytoprotective properties. Gastroenterology 1984; 86:1164.

145. Borrero E, Margolis I, Bank S, et al: A comparison between sucralfate and antiacids in the prevention of stress ulcers in critically ill patients. Gastroenterology $1984 ; 86: 1032$.

146. Fisher RS: Sucralfate: A review of drug tolerance and safety. $J$ Clin Gastroenterol 1981; 3(suppl 2):181-184.

147. Boyd EJS, Wilson JA, Wormsley KG: Recurrent ulcer disease, in Misiewicz JJ, Wood JR (eds): Ranitidine Therapeutic Advances. New York, Excerpta Medica, 1984, pp 14-41.

148. Thomson ABR, Mahachia V: Pharmacological management of patients with peptic ulcer disease: Prospects for the late 1980s. Clin Invest Med 1987; 10:152-170 